\title{
Bryn Mawr College
}

Scholarship, Research, and Creative Work at Bryn Mawr College

\section{The Beryozovo Cup: A Byzantine Object at the Crossroads of Twelfth-Century Eurasia}

\author{
Alicia Walker \\ Bryn Mawr College, awalker01@brynmawr.edu
}

Follow this and additional works at: https://repository.brynmawr.edu/hart_pubs

Part of the Medieval Studies Commons

Let us know how access to this document benefits you.

\section{Custom Citation}

Walker, A. 2018. "The Beryozovo Cup: A Byzantine Object at the Crossroads of Twelfth- Century Eurasia". Re-Assessing the Global Turn in Medieval Art History. Christina Normore and Carol Symes, eds.

Amsterdam: ARC, Amsterdam University Press: 125-148.

This paper is posted at Scholarship, Research, and Creative Work at Bryn Mawr College.

https://repository.brynmawr.edu/hart_pubs/109

For more information, please contact repository@brynmawr.edu. 


\title{
The Medieval Globe
}

Volume 3 | Number 2

Article 7

2017

\section{The Bereyozovo Cup: A Byzantine Object at the Crossroads of Twelfth-Century Eurasia}

\author{
Alicia Walker \\ Bryn Mawr College, awalker01@brynmawr.edu
}

Follow this and additional works at: https://scholarworks.wmich.edu/tmg

\section{Recommended Citation}

Walker, Alicia (2017) "The Bereyozovo Cup: A Byzantine Object at the Crossroads of Twelfth-Century Eurasia," The Medieval Globe: Vol. 3 : No. 2 , Article 7.

Available at: https://scholarworks.wmich.edu/tmg/vol3/iss2/7 


\section{THE \\ MEDIEVAL GLOBE}

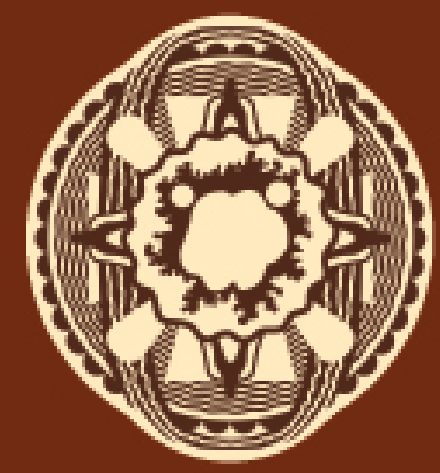

Volume 3.2 | 2017 


\section{THE \\ MEDIEVAL GLOBE}

Volume 3.2 | 2017 


\section{THE MEDIEVAL GLOBE}

The Medieval Globe provides an interdisciplinary forum for scholars of all world areas by focusing on convergence, movement, and interdependence. Contributions to a global understanding of the medieval period (broadly defined) need not encompass the globe in any territorial sense. Rather, $T M G$ advances a new theory and praxis of medieval studies by bringing into view phenomena that have been rendered practically or conceptually invisible by anachronistic boundaries, categories, and expectations. TMG also broadens discussion of the ways that medieval processes inform the global present and shape visions of the future.

Submissions are invited for future issues: please contact the Editorial Board (medievalglobe@illinois.edu). All articles will be evaluated by the editors and by a double-blind peer review process. For more information about TMG, with further details about submissions and peer review policy, please visit the journal's website: arc-humanities.org/our-series/arc/tmg.

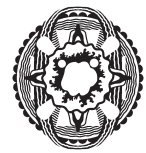

The mark of The Medieval Globe was designed by Matthew Peterson and draws on elements derived from six different medieval world maps.

\section{Executive Editor}

Carol Symes, University of Illinois at Urbana-Champaign

\section{Editorial Board}

James Barrett, University of Cambridge

Kathleen Davis, University of Rhode Island

Felipe Fernández-Armesto, University of Notre Dame

Elizabeth Lambourn, De Montfort University

Yuen-Gen Liang, National Taiwan University

Victor Lieberman, University of Michigan at Ann Arbor

Carla Nappi, University of British Columbia

Elizabeth Oyler, University of Pittsburgh

Christian Raffensperger, Wittenberg University

Rein Raud, University of Helsinki \& Tallinn University

D. Fairchild Ruggles, University of Illinois at Urbana-Champaign

Alicia Walker, Bryn Mawr College 


\title{
THE MEDIEVAL GLOBE
}

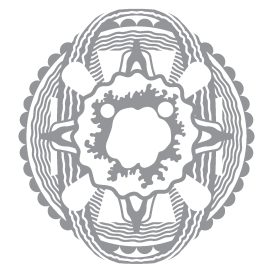

Volume 3.2 | 20 I 7

\section{Reassessing the Global Turn in Medieval Art History}

\author{
Edited by \\ CHRISTINA NORMORE
}

ARChumanities press 


\author{
Copyeditor \\ Kim Richardson \\ Editorial Assistant \\ Kelli McQueen \\ Page design and typesetting \\ Out of House Publishing
}

\title{
(C) 2017, Arc Humanities Press, Leeds
}

(c) (i) $\ominus$ This work is licensed under a Creative Commons Attribution-

cC) $\bigoplus_{\text {BY NC }}$ NonCommercial-NoDerivatives 4.0 International Licence.

The authors assert their moral right to be identified as the authors of their part of this work.

Permission to use brief excerpts from this work in scholarly and educational works is hereby granted provided that the source is acknowledged. Any use of material in this work that is an exception or limitation covered by Article 5 of the European Union's Copyright Directive (2001/29/EC) or would be determined to be "fair use" under Section 107 of the U.S. Copyright Act September 2010 Page 2 or that satisfies the conditions specified in Section 108 of the U.S. Copyright Act (17 USC §108, as revised by P.L. 94-553) does not require the Publisher's permission.

ISSN 2377-3561 (print)

ISSN 2377-3553 (online)

www.arc-humanities.org 


\title{
THE BERYOZOVO CUP:A BYZANTINE OBJECT AT THE CROSSROADS OF TWELFTH-CENTURY EURASIA
}

\begin{abstract}
ALICIA WALKER
BYZANTIUM IS PERHAPS best known for its sacred art. ${ }^{1}$ Haunting icons, breathtaking mosaics, immersive wall paintings, and otherworldly ecclesiastical architecture are among the hallmarks of the tradition. Yet, as one of the wealthiest and most cosmopolitan societies of the medieval world, the Byzantine Empire also generated an impressive body of art and architecture that was used in nonreligious practices. One such object is a gilded silver cup found in the Siberian town of Beryozovo on the Ob River (now modern Russia), an area where numerous medieval artifacts have been discovered (Plate 6.1). ${ }^{2}$ On the exterior bottom of the vessel is incised an Old Cyrillic inscription, which records its weight in a hand dated to the twelfth century. ${ }^{3}$ Medieval Rus' was part of the Orthodox Christian sphere and maintained active diplomatic, trade, and ecclesiastical relations with Byzantium. ${ }^{4}$ While the inscription suggests that the cup arrived in Rus' lands soon after its production, the vessel's form, technique, iconography, and style firmly support a Byzantine origin. ${ }^{5}$ Its specific region of manufacture is debated,
\end{abstract}

I am grateful to Amanda Luyster, Oya Pancaroğlu, Christina Normore, Carol Symes, and the anonymous reviewers, all of whom provided excellent suggestions for the improvement of this essay. Any shortcomings or errors remain, of course, my own.

I Following the convention of modern scholarship, I refer to the medieval eastern Roman Empire, with its capital at Constantinople, as "Byzantium." I acknowledge, however, the anachronistic nature of this term, which is first attested only in 1557, over one hundred years after the fall of the (eastern) Roman Empire to the Ottomans in 1453. Regarding the origin of the moniker and the legacy of cultural bias that it encodes and perpetuates, see Kaldellis, Hellenism, 42-43; Evans, ed., Byzantium, 5.

2 See Marshak and Kramarovsky, Sokrovishcha Priob'ia. Since 1867, the Beryozovo cup has been in the collection of the State Hermitage Museum, Saint Petersburg. For the historiography of this object and discussion of its provenance, see Piatnitsky, "K istorii postuleniia," 128-39.

3 Piatnitsky, "K istorii postuleniia”; Piatnitsky et al., Sinai, Byzantium, Russia, 100.

4 On the real and symbolic connections between Kievan Rus' and the Byzantine Empire, see Raffensperger, Reimagining Europe.

5 See Darkevich, Svetskoe iskusstvo Vizantii; Ballian and Drandaki, “Middle Byzantine Silver." 
however, with scholarly consensus split between a Constantinopolitan provenience and a provincial one. ${ }^{6}$ Nonetheless, all scholars agree that the Beryozovo cup is a work of high quality, produced for members of the empire's social elite. ${ }^{7}$

The polylobed wall of the cup creates 154 repoussé surfaces on which are embossed vignettes of feasting and entertainment in the top row, and depictions of real and fantastic beasts as well as vegetal designs in the lower rows. ${ }^{8}$ The motifs include dancers, musicians, acrobats, harpies, sphinxes, quadrupeds, birds, and flowers (Plate 6.2). These flora, fauna, and entertainers rotate around a centrally placed female figure, who is crowned and sits at a table (see Plates 6.1-3). The iconography adorning the exterior of the vessel evokes worldly pleasures, but as the cup was drained of liquid, its user would have encountered an unexpected motif on the interior bottom surface: a chased portrait of the military saint George, identified by a Greek inscription and depicted with a halo (Plate 6.4 and Plate 6.13 detail, right). Mounted on a horse, he is equipped with a spear, shield, and armour. ${ }^{9}$ A cloak is clasped at his right shoulder and flutters behind him. He is framed by tendrils, which evoke a natural setting.

It is not surprising that this luxurious object has fascinated scholars for over a century. ${ }^{10}$ Conspicuously absent from previous studies, however, is extended consideration of the way in which the iconographic combination of courtly entertainments and a warrior saint actively juxtaposes sacred and the secular motifs. ${ }^{11}$

6 A third attribution, proposing a Russian provenience, lacks sufficient support. For the Constantinopolitan position, see Darkevich, Svetskoe iskusstvo Vizantii, 321 and 324-25. For the provincial Byzantine position, see Bank, Prikladnoe iskusstvo Vizantii, 193-94; Marshak and Kramarovsky, Sokrovishcha Priob'ia, 142; Piatnitsky, "K istorii postuleniia."

7 For discussion of the Beryozovo cup in relation to other Byzantine objects and monuments that participated in artistic connections between the Byzantine and Eastern Islamic worlds, see Walker, "Integrated yet Segregated."

8 For a full iconographic analysis of the vessel's exterior decorative program, see Darkevich, Svetskoe iskusstvo Vizantii, 161-215.

9 For a survey of the iconographic types of Saint George in Byzantine art, see Walter, Warrior Saints, 109-44. Also see Grotowski, Arms and Armour.

10 For instance, Darkevich, Svetskoe iskusstvo Vizantii, especially 78-91 and 322; Bank, Byzantine Art, 22 and 312-13, figs. 215-17; Piatnitsky et al., Sinai, Byzantium, Russia, 100 (no. B82); Piatnitsky, “K istorii postuleniia," 128-39; Maguire and Maguire, Other Icons, 46-49.

I I In the Byzantine world, many social practices (and the objects employed in them) elided religious and non-religious authority, decorative programs, and functions. Indeed, there is no direct translation in medieval Greek for the modern term "secular." On this point, see Anthony Cutler, "Sacred and Profane." Scholars still grapple with how to reconcile this linguistic and conceptual difference. For instance, Eunice and Henry Maguire embrace the term "secular" in the title of their important survey of Byzantine art and "secular culture," but in 
Indeed, some scholars discuss the decorative program of the object without acknowledging the presence of Saint George at all. ${ }^{12}$ In other instances, his portrait is related to the motifs of flora and fauna on the grounds that he was a patron saint of animals and hunting. ${ }^{13}$ This explanation is unsatisfying, however, because it does not account for the full range of subjects elaborated on the vessel's exterior surface.

The lack of attention to Saint George may be due in part to the fact that this emphatically Christian motif on the interior of the cup seems at odds with the exoticizing character of the exterior of the vessel. Indeed, the lobed wall and the motifs that populate its segmented surface find compelling parallels in works of medieval Islamic art. ${ }^{14}$ While the Byzantine provenience of the cup is secure, its transcultural character challenges art historical taxonomies that assume tidy stylistic and iconographic distinctions between works produced by different medieval geographic, cultural, and religious groups. By blurring the expected boundaries between Byzantine and medieval Islamic art, the Beryozovo cup invites engagement with the cosmopolitan nature of Byzantine material culture, the transcultural identities of the people involved in its production and use, and the complex social environments in which it functioned.

While we do not know the specific circumstances of the Beryozovo cup's production or use, it was undoubtedly employed in elite dining. Recent studies have paved the way for understanding Byzantine luxury tableware as an actor in the social performance of the courtly banquet. Much as the Orthodox liturgy and imperial ceremonial were carefully orchestrated rituals of symbolic display, so feasting, too, was structured by rules of precedence and etiquette. ${ }^{15}$ In these ways, imperial

the introduction they frame their study as one of "unofficial" and "profane" art, noting that "official" (i.e. religious) and "unofficial" art were mutually dependent and defining: Maguire and Maguire, Other Icons, 1-2. In his recent consideration of the term "secular" in the interpretation of Byzantine tableware, Warren Woodfin ("Within a Budding Grove," especially 154-55) recognizes its anachronistic nature, but ultimately endorses its use, arguing that a discrete category for non-religious works of art is necessary in art historical analysis so as to avoid their being marginalized in (or even excluded from) scholarship on Byzantine art. For a broader discussion of the blurring between "secular" and "sacred" categories across medieval art and the shortcomings of "secular" as a heuristic, see Walker and Luyster, eds., Negotiating Secular and Sacred, 1-16, and the essays collected in that volume.

12 For example, Maguire and Maguire, Other Icons, 46-49.

13 See Darkevich, Svetskoe iskusstvo Vizanti, 144-49 and 322.

14 Darkevich, Svetskoe iskusstvo Vizantii, 163-75; Maguire and Maguire, Other Icons, 46-49.

15 On this point, see esp. Malmberg, "Visualizing Hierarchy," 11-24; Malmberg, "Dazzling Dining," 75-91. 
banquets were much more than pleasurable pastimes; these events reflected and reinforced social order and stability. ${ }^{16}$ Scholars have shown how the iconographic programs of dining vessels articulated participants' identities and further affirmed the power structure of the Byzantine court, which was diagrammed through carefully controlled seating arrangements that accommodated not only courtiers but also foreign emissaries and, in some instances, political hostages.

In this context, elaborate dining ware acted as an integral agent in the communication of Byzantine superiority and control. The Beryozovo cup combines conventional Byzantine iconography with visual vocabularies and forms that evoked broader cultural and political spheres that Byzantium strove to dominate. Even the quintessentially Byzantine portrait of Saint George evoked transcultural identities because, by the twelfth century, military saints had emerged as emblems of authority across medieval Eurasia, from western Europe to the Crusader states, and even in some Islamic territories. Saint George was a truly transcultural heroic figure, who communicated Byzantine military prowess in terms that were immediately legible to individuals from diverse regional, cultural, and religious backgrounds.

Although the Beryozovo cup was not necessarily made for "global" circulation, I argue that it reflected and promoted expanded, transcultural identities that resulted from the circulation of objects-as well as people and ideas-from beyond the distant borders of the empire to the court at Constantinople and from this epicentre throughout medieval Eurasia. As such, this case study recognizes how medieval globalism not only reshaped actual borders and pathways between cultural, economic, and political groups but also forged new mental geographies and conceptual frontiers that directly impacted the identities of people at the centres of socio-political power, and shaped the works of art they created. ${ }^{17}$

\section{The Beryozovo Cup within the Corpus of Middle Byzantine Elite Tableware}

The Beryozovo cup is one of several extant middle Byzantine (ca. 843-1204) metal vessels that were intended for use in elite dining and share features of form, size, workmanship, style, composition, and iconography. For instance, an eleventh-century vessel executed in silver repoussé has the image of another

16 For instance, see Leader-Newby, Silver and Society; Malmberg, "Visualizing Hierarchy"; Stone, "Eustathios"; Malmberg, "Dazzling Dining"; Maguire and Maguire, Other Icons, esp. 29-57. On tableware and feasting in the medieval Islamic world, see Pancaroğlu, "Feasts of Nishapur."

17 My understanding of medieval globalism is greatly informed by Eva Hoffman's seminal study "Pathways of Portability." Also see Walker, "Globalism." 
military saint, Theodore, on the interior of its base, although in bust form rather than as a mounted figure (Plates 6.5 and 6.6). ${ }^{18}$ While the iconographic programs of both vessels feature real and fantastic animals, the Saint Theodore cup prominently displays scenes of animal combat (and animals attacking humans), which are absent from the Beryozovo cup. Furthermore, only the latter includes images of banqueting and entertainments. The Saint Theodore cup does not have the same polylobed surface; instead, figures are arranged in two concentric circles. Some animals are positioned within round or teardrop frames, while others are rendered against an open field. Unlike the Beryozovo cup, the Saint Theodore cup was originally equipped with a handle and is fabricated from a single sheet of metal-rather than a double wall of silver, as in the case of the Beryozovo cup-such that the worked side of its repoussé decorations is visible on the interior. In addition, the Saint Theodore cup is significantly shorter in profile, being less than half the height of the Beryozovo cup $(5 \mathrm{~cm}$ versus $11.6 \mathrm{~cm}$ ). The two vessels are, however, of comparable diameter, and each cup would have fit easily in a person's hands, suggesting that they were intended for individual use. ${ }^{19}$

The decoration of another twelfth-century Byzantine drinking vessel is rendered in a larger scale than on the Beryozovo cup. In addition, the figures are executed in more pronounced repoussé and framed by an arcuated colonnade (Plate 6.7). ${ }^{20}$ Yet the decorative programs of the vessels employ a similar iconographic vocabulary that includes dancers and musicians as well as mounted warriors. A close stylistic and iconographic connection is also evident in the rims of the two vessels, which display the same incised motifs of racing animals interspersed with tendrils (Plate 6.8). Finally, both cups feature a double wall construction. The inner surface of the bottom of this cup displays addorsed griffins (Plate 6.9). In comparison to the Beryozovo cup, the height and diameter of this vessel are only slightly smaller (within $2 \mathrm{~cm}$ ), indicating that it was also designed for use by one person.

A final example further illustrates the similarity and diversity of these middle Byzantine dining vessels. In this case, only the upper section of a two-part,

18 Bank, Byzantine Art, 21 and 312, and figs. 212-14; Maguire and Maguire, Other Icons, 16-17.

19 The Theodore cup is slightly smaller in diameter, measuring $14 \mathrm{~cm}$ versus $18.5 \mathrm{~cm}$ for the Beryozovo cup.

20 Darkevich, Svetskoe iskusstvo Vizantii, figs. 83-84; Bank, Byzantine Art, 22 and 313, figs. 218-19; Piatnitsky et al., Sinai, Byzantium, Russia, 100-101, no. B83; Ballian and Drandaki, "Middle Byzantine Silver," 53 and 57. 
covered cup is preserved, and all the motifs are chased (Plate 6.10). ${ }^{21}$ The decorative program shows musicians, dancers, and acrobats around the outer surface and animals circling the top. Indeed, some motifs are strikingly similar to those on the Beryozovo cup: for instance, the image of an acrobat standing on his hands and lowering his body to drink from a cup that rests on the ground (compare Plate 6.11). The diameter of this vessel approximates that of the Beryozovo cup (the diameter of the latter is less than $2 \mathrm{~cm}$ larger); however, the original height of the lidded cup would have been substantially greater given that the lid alone is less than $3 \mathrm{~cm}$ shorter than the full height of the Beryozovo cup. Still, their overall dimensions indicate that each vessel was intended for use by a single person.

Looking beyond drinking vessels to the wider range of wares placed on the Byzantine banquet table, the Beryozovo cup's mounted rider finds a close parallel in two twelfth-century Byzantine plates purportedly discovered in Bulgaria (Plates 6.12 and 6.13). ${ }^{22}$ One of these dishes displays a framing motif of sprinting animals against foliage (see Plate 6.12), which closely parallels the ornament along the rims of the Beryozovo cup and other middle Byzantine drinking vessels (compare Plate 6.8). ${ }^{23}$ The riders depicted at the centre of these two plates are not labelled, nor do they have haloes. Unlike the motif of Saint George, which evokes both heroic and holy authority, these figures do not employ explicitly Christian symbols.

Together, these comparanda link the Beryozovo cup to a broader corpus of middle Byzantine elite tableware. They make clear not only the diversity of forms, techniques, and iconography that were employed in these objects, but also the points of commonality among the vessels, which include themes of feasting, courtly entertainment, hunting, and natural abundance, as well as close parallels in the style of decoration and the techniques of production.

\section{Islamic Models for the Beryozovo Cup}

The recurring images of feasting, dancing, music-making, and natural bounty on the Beryozovo cup have led some scholars to relate it to a "shared culture" of luxury objects that were enjoyed at courts throughout the wider medieval Mediterranean

21 Darkevich, Svetskoe iskusstvo Vizantii, fig. 165; Bank, Byzantine Art, 313, figs. 220-24; Ballian and Drandaki, "Middle Byzantine Silver," 53 and 59.

22 They are reported to have been recovered outside Tatar Pazarcik, Bulgaria. Ballian and Drandaki, "Middle Byzantine Silver," 47.

23 Ibid., 51-53. 
world, and beyond. ${ }^{24}$ Indeed, some of these vessels resonate thematically with the so-called "princely cycle" of medieval Islamic iconography, which showcases pastimes of the court. ${ }^{25}$ Similar motifs of elite pleasures rendered in an Islamic or Islamicizing style are found in the decoration of twelfth- and thirteenth-century objects and monuments over a vast geographic range and across a wide span of cultures. ${ }^{26}$ Still, to view the Beryozovo cup as participating in a generic, "shared culture" of courtly iconographies runs the risk of flattening its distinctiveness. While works of medieval art and architecture from other elite environments employ similar imagery, these objects and monuments frame and inflect this common visual language in different ways, so as to communicate ideas and identities that are specific to the individuals and communities that produced and used them. ${ }^{27}$

As noted above, some characteristics distinguish the Beryozovo vessel from surviving Byzantine comparanda and affiliate it more directly with Islamic models. In particular, the Beryozovo cup's unusual polylobed form does not find close parallels among other middle Byzantine metal vessels, but is a distinctive feature of several twelfth-century Islamic candlesticks. This corpus includes at least eight extant examples, which have been attributed proveniences in Afghanistan and Iran. ${ }^{28}$ The Iranian examples have been further localized to the region of Khorasan, specifically, the city of Herat. ${ }^{29}$ These areas experienced tremendous upheaval during the eleventh and twelfth centuries, when the medieval Islamic dynasties of the Great Seljuqs (1037-1194), the Ghurids (ca. 879-1215, whose capitals included Herat), and the Ghaznavids (977-1156) were engaged in intense competition

24 See Maguire and Maguire, Other Icons, 47-49. On the subject of the "shared culture" of medieval Islamic and Christian courts throughout the Mediterranean region, see Grabar, "Shared Culture."

25 Regarding Islamic iconographic comparanda for the Beryzovo cup and other middle Byzantine silver vessels, see Darkevich, Svetskoe iskusstvo Vizantii, 161-215. For an extensive iconographic compendium of "princely cycle" imagery, see Johns and Grube, Painted Ceilings; Shepherd, "Banquet and Hunt"; Shoshan, "High Culture," especially 72-74; Hoffman, "Between East and West."

26 For instance, see Tronzo, Cultures; Hoffman, "Fatimid Book"; Walker, The Emperor and the World, especially 108-64.

27 On this point, especially see Hoffman, "Pathways of Portability," 22-23. For additional studies that move beyond the reductive framework of the "shared culture" model, see, for example, Flood, Objects of Translation; Walker, The Emperor and the World.

28 Atıl et al., Islamic Metalwork, 98-99. Atıl notes seven of the examples; the eighth is in the Linden-Museum, Stuttgart.

29 Atıl et al., Islamic Metalwork, 99. 
and sustained military confrontation. ${ }^{30}$ The majority of these candlesticks feature either inscriptions or repeating floral or geometric patterns on the surface of the polylobes. However, in one example, a decorative program of real and fantastical animals bears a striking stylistic and iconographic resemblance to the Beryozovo cup (Plates 6.14 and 6.15; compare Plates 6.1-3). ${ }^{31}$ This candlestick is dated to the second half of the twelfth century; it is thought to have been produced in eastern Iran or Afghanistan and to be of Ghurid (or possibly Ghaznavid) production. ${ }^{32}$ The object is quite large, measuring about $33 \mathrm{~cm}$ in height with a base diameter of about $40 \mathrm{~cm}$, but because it is hollow it is extremely light and easy to move.

While the Byzantine Empire did not maintain diplomatic or commercial relations with the Ghurids (or Ghaznavids), twelfth-century realignments of power in Ghurid (and Ghaznavid) territories likely put large numbers of works of art into circulation, and may have made them accessible across a broader geographic and cultural sphere. Furthermore, the Seljuqs - who maintained extensive connections with Byzantium - could have played a role in transporting Ghaznavid and Ghurid objects westward, making them available to the Byzantines through trade or gift-giving. ${ }^{33}$ The polylobed form of the Beryozovo cup seems to have been distinctive to Islamic metalwork of the period, and its exotic form might have been chosen as a meaningful framing device for the portrait of Saint George; it worked in tandem with the "princely cycle" iconography to position the Christian saint within an Islamicizing frame, inviting the viewer to reflect on his status as a transcultural heroic figure.

\section{Hagiographical and Historical Narratives of Saint George}

How might medieval users of the Beryozovo cup have read the figure of Saint George in tandem with the banquet scene on its exterior wall? Saint George was said to have lived in the region of Cappadocia (in central Anatolia) during the fourth

30 Inaba, "Ghaznavids”; O’Neal, “Ghurids.”

31 Leth, David Collection, 71.

32 Regarding the art and architecture of the Ghurids and Ghaznavids and their transcultural character, see Flood, Objects of Translation. The candlestick in the Linden-Museum, Stuttgart, shows strong similarities to the candlestick in the David Collection, Copenhagen, and it is this comparison that supports a Ghurid attribution for the David Collection example. The Stuttgart candlestick includes an inscription naming the owner as a Ghurid court official and providing a date of 1166. See Blair, Text and Image, 63, 85-86. Also see Forkl, ed., Die Gärten, 82-85. I am grateful to Bekhruz Kurbanov for making his unpublished research on the Stuttgart candlestick available to me.

33 For concise discussions of Byzantine-Seljuq diplomatic, commercial, and social relations, see Necipoğlu, "Coexistence," and "Turks and Byzantines." Maria Vittoria Fontana has 
century, and this association led to the development of a vibrant local cult. In the tenth century, Saint George emerged as one of the foremost protectors of Christian communities in this eastern region of the Byzantine Empire. Cappadocian veneration of Saint George is well attested in wall painting, for example, in the eleventhcentury Ylanlı Kilise (Snake or Dragon Church) in Göreme (Plate 6.16). ${ }^{34}$ The regional popularity of Saint George and his role as a protector of the Christian frontier eventually spread to Constantinople in the mid-tenth century, when the militarized aristocracy of Cappadocia amassed significant political power, which eventually led to the rise of emperors Nikephoros II Phokas (r. 963-969) and John I Tzimisckes (r. 969-976), who both hailed from prominent Cappadocian families. ${ }^{35}$

In the eleventh century, however, Byzantium lost significant territories in Anatolia. Most infamously, Romanos IV Diogenes (r. 1068-1071) was defeated and captured by a Seljuq army at the Battle of Mantzikert in $1071 .{ }^{36}$ This loss destabilized Romanos's authority and contributed to a period of civil war that opened the way for Seljuq advances over the course of the eleventh and twelfth centuries. As a result, the empire lost control of its former territories in the East. These events had significant impact on the wider Eurasian geopolitical situation. Alexios I Komnenos (r. 1081-1118) cited the Battle of Mantzikert in his plea for papal assistance to combat the rise of Muslim "infidels," a call that eventually led to the launch of the First Crusade in $1095 .{ }^{37}$

Seen within this context, the Beryozovo cup's combination of Saint George with an Islamicizing form and iconography might be understood to evoke, for an informed viewer, the Eastern locale of the saint's life and cult as well as his role in protecting the empire from threats at its frontiers and in aiding Christian forces to reclaim territories from Islamic control. While we might be inclined to

identified Ghaznavid imitations of Byzantine ceramics that suggest commercial connections between these groups, which were possibly mediated by the Seljuqs: see "Note."

34 Walter, Warrior Saints, 125-31; Restle, Die byzantinische Wandmalerei, 1:129-30, 2: figs. 246-47.

35 On these leaders and their dedication to George and other military saints, see Walter, Warrior Saints, 131-38. Saint George was said to have intervened on behalf of Nikephoros II in 961 before he assumed the throne, and wall painting cycles featuring Saint George saw a sharp increase in popularity from the tenth to twelfth centuries; scholars have identified one such mural program dated to the tenth century and two dated to the eleventh century versus ten dated to the twelfth century.

36 For a summary of the circumstances surrounding the Battle of Mantzikert and its outcomes, see Kazhdan, "Mantzikert"; MacEvitt, Crusades, 40-43; Peacock, Great Seljuk Empire, 54-56.

37 See Lilie, Byzantium and the Crusader States, 1-28; Frankopan, First Crusade, 87-100. 
interpret this intermixing of Byzantine and Islamic artistic features to indicate a provenience at the eastern frontier of Byzantium, it is equally possible that the cup was produced and used at the empire's centre, in the cosmopolitan capital of Constantinople. ${ }^{38}$ In this case, the cup could be understood as a courtly object that responded to circumstances unfolding at Byzantium's borders, thereby evincing how seemingly marginal events at the edges of the empire impacted identity and self-representation at its core. George's multifaceted character-a Christian saint of eastern origin, who was a provincial soldier but demonstrated the refined character of a courtier-made him especially well-suited to communicate with viewers at both the centre and peripheries of Byzantium.

Another possible interpretation would tie the iconographic program of the cup's exterior more tightly to one of the stories that was woven into the Orthodox vita of the saint. In an eleventh-century Georgian version of his life, George was credited with saving the daughter of the idolatrous emperor Selinus from a dragon..$^{39}$ The vita reports that, when returning from service in Diocletian's army and while en route to his Cappadocian estate, George encountered the princess, who had been left as a sacrifice by her pagan father. ${ }^{40}$ George not only rescued her and pacified the dragon, but converted the emperor and his people to Christianity, after which a great celebration ensued. ${ }^{41}$ Scholars have long noted an unusual detail in the banquet scene on the Beryozovo cup, namely that the central figure at the table appears to be a woman. ${ }^{42}$ This raises the possibility that the imagery on the vessel's exterior alludes to the princess's rescue by George and the subsequent

38 Regarding issues surrounding the production and consumption of Byzantine luxury arts, including metalwork, see Cutler, "Industries of Art," especially 569-75; Cutler, "Uses of Luxury."

39 Walter, "Origins," especially 320-22. The earliest Greek version of the story dates to the twelfth or thirteenth century and follows the Georgian model closely.

40 Walter (Warrior Saints, 140-42) notes that the story probably was established and depicted by the twelfth century.

4I George is associated with one other instance of banqueting: in a posthumous miracle, he is said to have rescued a boy from Mytilene (on the island of Lesbos) who had been captured by Arab pirates and made to serve the emir of Crete as a cup bearer. In a well-known Crusader icon that illustrates the event, the boy holds a distinctly Islamic beaker in his hand to indicate that he has just been rescued from domestic servitude. For discussion of this narrative and its iconography, see Cormack and Mihalarias, "Crusader Painting"; Walter, Warrior Saints, 120 and 138, pl. 58.

42 For instance, Darkevich, Svetskoe iskusstvo Vizantii, 81; Ballian and Drandaki, "Middle Byzantine Silver," 51. In both cases, the authors identify the female figure as a Byzantine empress and interpret the banquet scene as a courtly genre vignette. 
celebration of her deliverance, thereby providing a narrative context for both the banquet on the exterior of the vessel and the portrait of a triumphant saint on its interior. The vessel's polylobed form could also evoke the exotic, eastern borderland setting of these events. At the same time, the conversion of the princess and her pagan people and their absorption into the Christian oikoumene parallels the artistic assimilation of Islamic iconography and forms, here mastered by Byzantine artists and produced for Byzantine consumption. In this way, the cup becomes a subtle statement about the proselytizing potential of Christianity and its capacity to assimilate diverse individuals and traditions. While this message is certainly religious, it is also militaristic and political.

\section{Military Saints across the Borders of Twelfth-Century Anatolia}

As Byzantine power in Anatolia waned in the years following the Battle of Mantzikert, multiple Turkic peoples, foremost the Seljuq Sultanate of Rum (10811307), competed to control the territory. In this process, they integrated Roman and Byzantine material culture and traditions with Islamic political and cultural identities. This phenomenon is particularly well illustrated by a twelfth-century coin (Plate 6.17), which features a mounted rider attacking a dragon-a figure strikingly similar to Saint George-as the emblem of the last Danishmendid ruler of Malataya, Nasir al-Din Muhammad (r. 1162-1170 and 1175-1178), who was defeated by the Seljuqs of Rum in $1178 .{ }^{43}$ The process of cultural absorption extended beyond the political sphere to include the repurposing of the cults of regional military saints. ${ }^{44}$ The Christian holy warriors George and Theodore were translated into the popular Islamic figure al-Khidr, and cult sites formerly dedicated to these Christian saints were appropriated for Islamic use. ${ }^{45}$

Keeping these developments in mind, we can view the portrait of Saint George on the Beryozovo cup in a new light. While the exterior of the vessel frames the saint

43 Pancaroğlu, "Itinerant Dragon-Slayer," 156-57. The Seljuqs of Rum also produced coins depicting dragon-slaying figures. See also Shukurov, "Turkmen"; Georganteli, "Transposed Images."

44 Pancaroğlu, "Itinerant Dragon-Slayer;" Wolper, "Khiḍr," "Khiḍr and the Changing Frontiers," and "Khidir and the Politics of Place."

45 Among the best known of these transformations, elements from a church of Saint Theodore in the area of Euchaita (Avkat, Turkey) were reused in the construction of a nearby dervish lodge. Pancaroğlu, "Itinerant Dragon-Slayer," 151; Wolper, "Khiḍr," 313-16. Regarding western Europeans' and Crusaders' possible awareness of al-Khidr, see Ng and Hodges, "Saint George." 
within a visual vocabulary of Islamic luxury and power, the interior portrait-with its Greek inscription and distinctively Orthodox style and iconography-insists on the integrity of his Byzantine identity. In this way, the object mirrors a contemporary socio-political climate in which the alarming loss of Byzantine territories transpired alongside the accrual of ever more intimate familiarity with SeljuqIslamic culture and increased fluency in this adversary's visual culture. This situation heightened a need for the Byzantine court simultaneously to compete with and distinguish itself from this threatening "other." The transcultural character of Saints George and Theodore-as well as the monuments and objects associated with them and their cults-was amplified by their accumulation of new significance within the regional social and religious landscape of Islamic Anatolia.

\section{Saint George at the Banquet}

The iconography of the Beryozovo cup (and related items of elite middle Byzantine dinnerware) was further animated in the context of imperial and aristocratic banquets, events at which the host's and guests' status and cultural identities were staged to reify social order and authority. Indeed, tenth-century Byzantine court protocol manuals instruct their readers in conventions of precedence and the required placement of guests at imperial banquets. ${ }^{46}$ This display was carried out for the benefit of a Byzantine audience as well as for foreign visitors. Within the highly charged social practice of elite dining, tableware could play an active role in advertising Byzantine power by means of the conspicuous consumption of precious materials and the conspicuous display of objects that communicated pointed messages through their iconographic programs. ${ }^{47}$

A detailed account of one such banquet describes how the emperor Manuel I Komnenos (r. 1143-1180) hosted a spectacular feast in celebration of the marriage of his son, Alexios II Porphyrogennetos, to Agnes, the daughter of the Frankish king Louis VII (r. 1137-1180), on 2 March $1180 .{ }^{48}$ Court banquets were ordinarily held in the imperial palace, but this unusually extravagant event took place in the hippodrome in Constantinople and involved a marvellous display of food and drink,

46 This type of manual, known as a kletorologion, derives its name from the Greek word kletorion (banquet). The best known is attributed to Philotheos, who was the atriklines (chief of banquets) at the Byzantine court in the late ninth to early tenth century. See Oikonomides, Les Listes; Kazhdan, "Philotheos."

47 On this point, also see Maguire and Maguire, Other Icons, 46-57.

48 For discussion of an illustrated manuscript produced for Agnes, which instructs her in the process of acculturation in Byzantine elite society, see Hilsdale, "Constructing a Byzantine Augusta." 
as well as massive logistical challenges. The event also celebrated the marriage of Manuel's daughter, Maria Porphyrogenneta, to Renier, son of the powerful Latin marquess William of Montferrat. ${ }^{49}$ This was one of many occasions when Manuel welcomed well-connected European guests to the court, while he schemed to preserve and advance Byzantine interests in the Holy Land. Indeed, imperial banquets could be cast metaphorically as battles. On this occasion, Manuel commissioned the premier Greek rhetorician, Eustathios of Thessalonike (ca. 1115-1195), to compose an encomium in celebration of the event. In a striking passage, Eustathios compares the tables of the nuptial feast with "tables of another kind" on which the emperor distributes not celebratory fare but instead "the flesh of the barbarians." At the banquet of the battle, "the guests" are not Byzantine and Latin courtiers, but instead "flocks of vultures, who rejoice in feasting on such things." ${ }^{50}$ The passage credits the peace and unity enjoyed at the wedding table to Manuel's ability to keep barbarian foes at bay.

Eustathios also offers a perspective on the iconographic program of the Beryozovo cup. Among the diverse real and fantastical beasts that decorate the lower registers of the vessel appear several harpies, who are depicted as birds with the heads of human women (see Plate 6.2). In a passage of his poem, Eustathios refers to the harpies, evoking the mythological narrative in which they plagued the legendary Phineus by stealing his food and fouling his table. Eustathios playfully equates the harpies with low-ranking members of the court, who were not assigned seats at the feast, as well as to the grasping poor, who sought to steal scraps from the banquet platters. ${ }^{51}$ These hybrid creatures evoke in humorous terms the agonistic undertones of the banquet environment. At a subsequent point in the text, however, harpies entertain the emperor's guests with witty comments and amusing jests, suggesting that their presence at the banquet was not necessarily unwelcome. ${ }^{52}$

The Komnenian double wedding of 1180 evinces the close relationship of the Komnenian court to elites of western Europe. The Crusades brought an influx of Westerners to Constantinople as diplomatic envoys and guests in transit to the Holy Land. ${ }^{53}$ On ceremonial occasions of transcultural mingling, a vessel like the Beryozovo cup could have communicated a nuanced message to a Latin user, who

49 Wirth, ed., Eustathii Thessalonicensis, 170-81; Stone, “Eustathios," 33-42.

50 Stone, “Eustathios," 38; Wirth, ed., Eustathii Thessalonicensis, 173 (1. 35)-74 (1. 40).

5 I Stone, "Eustathios," 38-39; Wirth, ed., Eustathii Thessalonicensis, 174 (1. 64) and 17 (1. 78).

52 Wirth, ed., Eustathii Thessalonicensis, 174-76; Maguire and Maguire, Other Icons, 53-54.

53 Regarding Byzantium's relations with western European and Crusaders states as well as the presence of Latin Christians at the twelfth-century court at Constantinople, see Lilie, Byzantium and the Crusader States; Ciggaar, West and Byzantium; MacEvitt, Crusades. 
would first encounter the exoticizing exterior iconography of elite pleasures. But having drained the vessel of its contents, this same user would have registered a sobering message of Byzantine military prowess and Orthodox Christianity's special relationship with one of the most renowned of soldier saints. Indeed, recognition of Byzantium's particular hold on Westerners' conception of Saint George is demonstrated by early depictions of the saint in Europe, which employ Orthodox iconographic types. ${ }^{54}$

The Byzantines were not alone in promoting George as an otherworldly bulwark against Muslim adversaries; the saint also emerged prominently in Crusader hagiography and veneration. ${ }^{55}$ Several Latin historians even claimed that he-and an elite force of other holy protectors-fought alongside Crusader forces in 1098 as they battled for Antioch. ${ }^{56}$ In recognition of George's support, the Crusaders renewed his cult in the Holy Land, rededicating and expanding the church that had been founded around 530 at Lydda (Ramla) near Jerusalem. ${ }^{57}$ They also encountered the Orthodox iconography of the saint at the numerous Eastern Christian cult sites dedicated to him throughout the Holy Land. ${ }^{58}$ Although the artistic programs of these churches tend to be poorly preserved, a rare, intact wall painting from the eleventh-century phase of decoration at the Syrian Orthodox church of Deir Mar Musa al-Habashi (located about $80 \mathrm{~km}$ northeast of Damascus) depicts Saint George in familiar iconographic terms as a mounted warrior (Plate 6.18). ${ }^{59}$ In addition, he appeared on Crusader coinage, for example on the copper coins minted at Antioch and issued by Roger of Salerno (Plate 6.19), who was the regent (1112-1119) for Bohemund II, prince of Antioch (r. 1111-1119).$^{60}$ Among both Crusaders and western Europeans, Saint George's affiliation with the East was well noted. If intended for use by a western European or Crusader, the Beryozovo cup

54 These monuments include a wall painting at the church of Saint Botolph in Hardham, West Sussex, which has been dated to the late eleventh or early twelfth century. Park, "Lewes Group," 217-22.

55 See de Laborderie, "Richard the Lionheart"; MacGregor, "Ministry of Gerold d'Avranches"; MacGregor, "Negotiating Knightly Piety"; Folda, "Mounted Warrior Saints"; Lapina, "Demetrius of Thessaloniki."

56 Anon., Deeds of the Franks, 69. See MacGregor, "Negotiating Knightly Piety," 324-32. Regarding the importance of Orthodox Christian saints in the new devotional practices of the Crusaders, see Lapina, "Demetrius of Thessaloniki."

57 Walter, Warrior Saints, 112; MacGregor, “Negotiating Knightly Piety," 332-42.

58 See Immerzeel, “Holy Horsemen," “Divine Calvalry," and Identity Puzzles.

59 Immerzeel, Identity Puzzles, 56-67, especially 60-61, pl. 25; Immerzeel, "Holy Horsemen," 41-42, pl. 11.

60 Metcalf, Coinage, 28, no. 9 and pl. 6, nos. 95-101. 
would have presented a mutually revered holy person, creating a sense of shared values between Orthodox and Latin Christians. At the same time, the distinctly Byzantine style and iconography of the figure asserted Orthodox Christianity as the source for the image of this most powerful of military saints, thereby laying claim to a mediating role for Byzantium between Latin Christians and the holy person whose aid they so earnestly sought. ${ }^{61}$

The Beryozovo cup may have offered a different but equally powerful message to still another population of foreigners who frequented the Byzantine court in the twelfth century: Seljuq political refugees, diplomatic envoys, and even rulers. The first Seljuq (of Rum) leader to visit the Byzantine court was the Sultan of Ikonion, Masud I (r. 1116-1155; son of Kılıç Arslan I), who fled to Constantinople after his brother, Arab, unseated him in 1124, during the reign of John II Komnenos (r. 1118-1143). ${ }^{62}$ Even more noteworthy was the visit of one of Masud's sons, Kılıç Arslan II (r. 1156-1192), who sought support from Manuel I in 1161 after being defeated by the Danishmendids, who had allied with the Byzantines against the Seljuqs. ${ }^{63}$ In order to gain Manuel's support, Kılıç Arslan II was forced to take an oath of fealty to the emperor. The chronicle recording his visit to Constantinople reports that, on each of the forty-five days that he resided at court, Kılıç Arslan was sent food on gilded silver plates. During a final meal in the company of the emperor, he received all ninety plates in a show of imperial largesse, disposable wealth, and political power. ${ }^{64}$ The chronicle does not specify that these plates were decorated, but another source describes a different set of gilded dishes made to commemorate Manuel I's victory over Kilıç Arslan's father in 1146. The scenes decorating these vessels were said to have showcased the emperor's superior military skills and the sultan's defeat. ${ }^{65}$ Indeed, as numerous scholars have noted, the Komnenians, and Manuel in particular, actively used works of art in diverse media to project political claims. ${ }^{66}$ Paul Magdalino has speculated that the dishes given

6I Such assertions of Byzantine precedence may have been pointed responses to Crusader efforts to co-opt premier military saints as divine protectors and advocates. Lapina ("Demetrius of Thessaloniki") argues that the Crusaders' celebration of Saint Theodore's assistance at the Battle of Antioch was intended to undermine Byzantine authority and to solidify the Crusaders' political claims to Antioch against those of the emperor Alexios I Komnenos.

62 Korobeinikov, "Sultan," 94.

63 Ibid., 94-96.

64 Chabot, ed. and trans., Chronique, 3:319; Maguire and Maguire, Other Icons, 55-57.

65 Mango, Art, 228.

66 Magdalino and Nelson, "Emperor," esp. 132-51. 
to Kılıç Arslan II may have been worked with images of Byzantine dominance over Seljuq adversaries, perhaps even over the sultan himself. ${ }^{67}$ Unfortunately for Manuel, the military prowess he celebrated in art was not always realized in fact. Kılıç Arslan later broke his pledge and defeated Manuel's forces at the Battle of Myriokephalon in 1176, a humiliation that did not go unnoticed by western European and Crusader elites at the time. ${ }^{68}$

Perhaps even more significant than these visits by Seljuq rulers was the presence of numerous lower-ranking Seljuq émigrés who are known to have defected to the Byzantine court in the eleventh and twelfth centuries. ${ }^{69}$ These individuals joined the Komnenian aristocratic hierarchy and assimilated into Byzantine society, usually converting to Orthodox Christianity in the process. A prominent family representing this larger phenomenon was the Axouch clan, whose patriarch, John, was taken captive as a child in 1097, during the First Crusade. He subsequently entered the court of Alexios I Komnenos (r. 1081-1118), rising to power under his heir, John II Komnenos. John Axouch's own son, Alexios Axouch, also held positions of trust and authority under the Komnenian emperors, but fell from power during the reign of Manuel I and was confined to a monastery in $1167 .{ }^{70}$ Rustam Shukurov notes that some Seljuq refugees seeking safe haven at the Byzantine court may have been attracted to this destination because they were themselves half-Greek. Based on the documented instances of Byzantine women who married Seljuq courtiers, Shukurov posits that the harems of the Seljuq elite included a significant population of Greek-speaking, Orthodox women, who raised children fluent in Greek and familiar with Orthodox Christian devotional practices. ${ }^{71}$ These half-Greek, half-Seljuq offspring thus possessed linguistic, ethnic, and religious affiliations that produced decidedly transcultural identities, which simultaneously put them at odds with the majority cultures of the Byzantine and Seljuq courts and equipped them to adapt to and survive within either one of these socio-cultural environments.

An elite Seljuq viewer-whether an emissary, a hostage, or a refugeewho encountered an object like the Beryozovo cup at the Byzantine banquet table might have noted an echo of the dining ware familiar from Islamic courtly

67 Magdalino, Empire of Manuel I, 473-75.

68 Foss, “Myriokephalon”; Magdalino, Empire of Manuel I, 98-100, 458-59.

69 On this topic, see esp. Brand, "Turkish Element"; Necipoğlu, "Coexistence," and "Turks and Byzantines," 3-6; Shukurov, "Harem Christianity."

70 Kazhdan and Cutler, "Axouch." Regarding the misfortunes of the scion of this family, John Komnenos Axouch, see Walker, The Emperor and the World, 144-64.

7I Shukurov, "Harem Christianity." 
environments. ${ }^{72}$ In particular, Seljuq viewers may have recognized both the vessel's polylobed form and its familiar "princely cycle" iconography. Yet, as they drank from the cup and were eventually confronted by the portrait of Saint George, their reactions may have become more conflicted. The warrior saint and his iconography might have evoked regional cult sites in the Anatolian landscape that had been converted from Christian to Islamic use, thereby recalling Seljuq conquest of Byzantine territories. At the same time, the emphatically Byzantine character of George's portrait (and the Greek inscriptions framing it) professed a firm claim to him as a protector of Orthodox Christians. As a result, the cup projected a message that was, by turns, hospitable and hostile: Seljuq users might have been put at ease by the familiarity of the form and iconography displayed on the exterior of the cup, but then put on warning when Byzantine military prowess and supernatural allegiance were unexpectedly asserted as the cup was drained.

\section{Conclusion}

While it is impossible to know exactly who used the Beryozovo cup, or at what specific moments it was employed, we can appreciate that it strongly reflects the dynamic environment of the twelfth-century Byzantine court, through which western European, Crusader, and Seljuq elites circulated regularly, dining in the company of Byzantine aristocrats at tables laid by the Komnenian emperors. In such circumstances, the cup projected an image of cosmopolitan luxury but it also conveyed the privileged relationship between Byzantium and the most revered of supernatural military allies, Saint George. This message was aimed at foreigners, both Christians and Muslims, who needed to be kept in check with constant reminders of Byzantium's once and future authority over Anatolia and the Holy Land, but also at the emperor's own courtiers, who were aware of the Komnenians'

72 While there are no direct parallels between the form and iconography of the Beryozovo cup and Seljuq drinking vessels, a late twelfth- to early thirteenth-century Seljuq gilded silver bowl in the Keir Collection shows a single row of repoussé polylobes chased with images of harpies and vegetal motifs that show remarkable similarities of form and iconography to another twelfth-century Byzantine gilded silver cup in the State Hermitage Collection: see Canby et al., eds., Court and Cosmos, 268 (no. 169); Darkevich, Svetskoe iskusstvo Vizantii, 14-59. Their strong parallels further substantiate an argument for the intercultural nature of elite dining practices across the Byzantine and Seljuq worlds. For examples of additional twelfth-century Seljuq metal and ceramic drinking vessels and tableware, many of which feature "princely cycle" imagery of elite revelry and motifs of natural abundance, see Canby et al., Court and Cosmos. 
intense diplomatic and military struggles to assert control in the midst of a highly unstable geopolitical situation.

The emperor entertained a diverse audience at his feasts, but these Byzantine, Seljuq, western European, and Crusader participants possessed an increasingly merged visual and conceptual language, which the emperor could confidently deploy in order to communicate these messages. We can therefore appreciate the Beryozovo cup as an object that had the capacity to project the cultural and geographic realities of twelfth-century Anatolia and the Holy Land onto the epicentre of Byzantine society and politics at Constantinople. Yet, appropriately enough, this object also attests to the porous nature of imperial boundaries and the profound social mixing of the Byzantine, Seljuq, western European, and Crusader worlds. Positioned within this complex network, the cup invites distinct but intersecting modes of reception. Its imagery drew from multiple artistic traditions to construct a transcultural message of social and political authority that has been muted by the modern insistence on monolithic categories of secular and sacred, Christian and Islamic. Indeed, we might imagine that the cup's viewers and users were not only capable of perceiving its iconography as a unified program of heavily politicized courtly and heroic imagery, but might also have considered any object that failed to invoke these multiple domains of identity and power to fall short of constructing an image that could compete effectively in the tumultuous and cut-throat environment of twelfth-century Eurasia. 


\section{Bibliography}

Anonymous. The Deeds of the Franks and the Other Pilgrims to Jerusalem (Gesta Francorum et aliorum Hierosolymitanorum). Edited and translated by R. Hill. London: Nelson, 1962.

Atıl, Esin, et al. Islamic Metalwork at the Freer Gallery of Art. Washington, DC: The Gallery, Smithsonian Institution, 1985.

Ballian, Anna, and Anastasia Drandaki. "A Middle Byzantine Silver Treasure." Museio Benaki 3 (2003): 47-80.

Bank, Alice V. Byzantine Art in the Collections of Soviet Museums. New York: Abrams, 1978, 1977.

—. Prikladnoe iskusstvo Vizantii IX-XII vv.: očerki. Moscow: Nauka, 1978.

Blair, Sheila S. Text and Image in Medieval Persian Art. Edinburgh: Edinburgh University Press, 2014.

Brand, Charles M. "The Turkish Element in Byzantium, Eleventh-Twelfth Centuries.” Dumbarton Oaks Papers 43 (1989): 1-25.

Canby, Sheila R., et al., eds. Court and Cosmos: The Great Age of the Seljuqs. New York: Metropolitan Museum of Art, 2016.

Chabot, J. B., ed. and trans. Chronique de Michel le Syrien patriarche Jacobite d'Antioche (1166-1199), 4 vols. Brussels: Culture et Civilisation, 1963.

Ciggaar, Krijna Nelly. The West and Byzantium, 962-1204: Cultural and Political Relations. Leiden: Brill, 1996.

Cormack, Robin, and Stavros Mihalarias. "A Crusader Painting of St. George: 'Maniera greca' or 'lingua franca'." Burlington Magazine 126 (1984): 132-41.

Cutler, Anthony. "Industries of Art." In The Economic History of Byzantium: From the Seventh through the Fifteenth Century, edited by Angeliki Laiou, 555-87. Washington DC: Dumbarton Oaks, 2002.

—. "Sacred and Profane: The Locus of the Political in Middle Byzantine Art." In Arte profana e arte sacra a Bisanzio, edited by Antonio Iacobini, 315-38. Rome: Argos, 1995.

—. "Uses of Luxury: On the Function of Consumption and Symbolic Capital in Byzantine Culture." In Byzance et les images, edited by A. Guillou and J. Durand, 287-327. Paris: La Documentation française, 1994.

Darkevich, Vladislav P. Svetskoe iskusstvo Vizantii: Proizvedeniia vizantiisk. khudozh. remesla v Vost. Evrope X-XIII v. Moscow: Iskusstvo, 1975.

Evans, Helen C., ed. Byzantium: Faith and Power (1261-1557). New York: Metropolitan Museum of Art, 2004.

Flood, Finbarr Barry. Objects of Translation: Material Culture and Medieval "HinduMuslim" Encounter. Princeton: Princeton University Press, 2009.

Folda, Jaroslav. "Mounted Warrior Saints in Crusader Icons: Images of the Knighthoods of Christ." In Knighthoods of Christ: Essays on the History of the 
Crusades and the Knights Templar, Presented to Malcolm Barber, edited by Norman Housley, 87-105. Aldershot: Ashgate, 2007.

Fontana, Maria Vittoria. "A Note on the Relationship between Some Ghaznavid and Byzantine Grafitta Wares." East and West 55.1/4 (2005): 117-27.

Forkl, Hermann, ed. Die Gärten des Islam. Stuttgart: Mayer, 1993.

Foss, Clive F. W. "Myriokephalon." In The Oxford Dictionary of Byzantium, 3 vols., edited by Alexander Kazhdan et al., 2:1430. Oxford: Oxford University Press, 1991.

Frankopan, Peter. The First Crusade: The Call of the East. Cambridge, MA: Belknap Press, 2012.

Georganteli, Eurydice. "Transposed Images: Currencies and Legitimacy in the Late Medieval Eastern Mediterranean.” In Byzantines, Latins, and Turks in the Eastern Mediterranean World after 1150, edited by Jonathan Harris, Catherine Holmes, and Eugenia Russell, 141-79. Oxford: Oxford University Press, 2012.

Grabar, Oleg. "The Shared Culture of Objects.” In Byzantine Court Culture from 829 to 1204, edited by Henry Maguire, 115-29. Washington, DC: Dumbarton Oaks, 1995.

Grotowski, Piotr L. Arms and Armour of the Warrior Saints: Tradition and Innovation in Byzantine Iconography (843-1261). Leiden: Brill, 2010.

Hilsdale, Cecily. "Constructing a Byzantine Augusta: A Greek Book for a French Bride." Art Bulletin 87.3 (2005): 458-83.

Hoffman, Eva. "Between East and West: The Wall Paintings of Samarra and the Construction of Abbasid Princely Culture." Muqarnas 25 (2008): 107-32.

—. "A Fatimid Book Cover: Framing and Reframing Cultural Identity in the Medieval Mediterranean World." In L'Égypte fatimide: Son art et son histoire, edited by Marianne Barrucand, 403-20. Paris: Université Paris-Sorbonne, 1999.

—. "Pathways of Portability: Islamic and Christian Interchange from the Tenth to the Twelfth Century." Art History 24.1 (2001): 17-50.

Immerzeel, Mat. "Divine Calvalry: Mounted Saints in Middle Eastern Christian Art." In East and West in the Crusader States: Context-Contacts-Confrontations III, edited by K. Ciggaar and H. Teule, 265-86. Leuven: Peeters, 2000.

—. "Holy Horsemen and Crusader Banners: Equestrian Saints in Wall Paintings in Lebanon and Syria." Eastern Christian Art 1 (2004): 29-60.

—. Identity Puzzles: Medieval Christian Art in Syria and Lebanon. Leuven: Peeters, 2009.

Inaba, Minoru. "Ghaznavids." In Encyclopaedia of Islam, Three, ed. Kate Fleet et al. http://dx.doi.org/10.1163/1573-3912_ei3_COM_27454 [accessed 5 June 2017]. 
Johns, Jeremy, and Ernst Grube. The Painted Ceilings of the Cappella Palatina. Genova: Bruschettini Foundation for Islamic and Asian Art, 2005.

Kaldellis, Anthony. Hellenism in Byzantium: The Transformations of Greek Identity and the Reception of the Classical Tradition. Cambridge: Cambridge University Press, 2007.

Kazhdan, Alexander. "Mantzikert, Battle of." In The Oxford Dictionary of Byzantium, 3 vols., edited by Alexander Kazhdan et al., 2:1288-89. Oxford: Oxford University Press, 1991.

—. "Philotheos, Kletorologion of." In The Oxford Dictionary of Byzantium, 3 vols., edited by Alexander Kazhdan et al., 3:1661-62. Oxford: Oxford University Press, 1991.

—, and Anthony Cutler. "Axouch." In The Oxford Dictionary of Byzantium, 3 vols., edited by Alexander Kazhdan et al., 1:239. Oxford: Oxford University Press, 1991.

Korobeinikov, Dimitri. "A Sultan in Constantinople: The Feasts of Ghiyāth al-Dīn Kay-Khusraw I." In Eat, Drink, and Be Merry (Luke 12:19): Food and Wine in Byzantium, edited by Leslie Brubaker and Kallirroe Linardou, 93-108. Aldershot: Ashgate, 2007.

Laborderie, Olivier de. "Richard the Lionheart and the Birth of a National Cult of St. George in England: Origins and Development of a Legend." Nottingham Medieval Studies 39 (1995): 37-52.

Lapina, Elizabeth. "Demetrius of Thessaloniki: Patron Saint of Crusaders." Viator 40.2 (2009): 93-112.

Leader-Newby, Ruth. Silver and Society in Late Antiquity. Functions and Meanings of Silver Plate in the Fourth to Seventh Centuries. Aldershot: Ashgate, 2004.

Leth, André. The David Collection: Islamic Art. Copenhagen: Davids Samlin, 1975.

Lilie, Ralph-Johannes. Byzantium and the Crusader States, 1096-1204. Oxford: Oxford University Press, 1993.

MacEvitt, Christopher. The Crusades and the Christian World of the East: Rough Tolerance. Philadelphia: University of Pennsylvania Press, 2008.

MacGregor, James. "The Ministry of Gerold d'Avranches: Warrior-Saint and Knightly Piety on the Eve of the First Crusade." Journal of Medieval History 29 (2003): 219-37.

—. "Negotiating Knightly Piety: The Cult of the Warrior-Saints in the West, ca. 1070-ca. 1200." Church History 73.2 (2004): 317-45.

Magdalino, Paul. The Empire of Manuel I Komnenos, 1143-1180. Cambridge: Cambridge University Press, 1993.

— , and Robert Nelson. "The Emperor in Byzantine Art of the Twelfth Century." Byzantinische Forschungen 8 (1982): 123-83.

Maguire, Eunice Dauterman, and Henry Maguire. Other Icons: Art and Power in Byzantine Secular Culture. Princeton: Princeton University Press, 2007. 
Malmberg, Simon. "Dazzling Dining: Banquets as an Expression of Imperial Legitimacy." In Eat, Drink, and Be Merry (Luke 12:19): Food and Wine in Byzantium, edited by Leslie Brubaker and Kallirroe Linardou, 75-91. Aldershot: Ashgate, 2007.

—. "Visualizing Hierarchy at Imperial Banquets." In Feast, Fast or Famine: Food and Drink in Byzantium, edited by Wendy Mayer and Silke Trzcionka, 11-24. Brisbane: Australian Association for Byzantine Studies, 2005.

Mango, Cyril. The Art of the Byzantine Empire, 312-1453. Englewood Cliffs, NJ: Prentice-Hall, 1972.

Marshak, Boris, and M. G. Kramarovsky. Sokrovishcha Priob'ia. Saint Petersburg: Formika, 1996.

Metcalf, D. M. Coinage of the Crusades and the Latin East in the Ashmolean Museum Oxford, 2nd ed. London: Royal Numismatic Society, 1995.

Necipoğlu, Nevra. "The Coexistence of Turks and Greeks in Medieval Anatolia (Eleventh-Twelfth Centuries)." Harvard Middle Eastern and Islamic Review 5 (1999-2000): 58-76.

—. "Turks and Byzantines (Eleventh to Twelfth Centuries)." In The Turkic Speaking Peoples: 2,000 Years of Art and Culture from Inner Asia to the Balkans, edited by Ergun Çağatay and Doğan Kuban, 254-65. Munich: Prestel, 2006.

$\mathrm{Ng}$, Su Fang, and Kenneth Hodges. "Saint George, Islam, and Regional Audiences in Sir Gawain and the Green Knight." Studies in the Age of Chaucer 32 (2010): 257-94.

Oikonomides, Nicolas. Les Listes de préséance byzantines des IXe et Xe siècles. Paris: Éditions du Centre national de la recherche scientifique, 1972.

O’Neal, Michael. "Ghurids." In Encyclopaedia of Islam, Three, ed. Kate Fleet et al. http://dx.doi.org/10.1163/1573-3912_ei3_COM_27477 [accessed 5 June 2017].

Pancaroğlu, Oya. "Feasts of Nishapur: Cultural Resonances of Tenth-Century Ceramic Production in Khurasan." In Harmony: The Norma Jean Calderwood Collection of Islamic Art, edited by Mary McWilliams, 3-13. Cambridge, MA: Harvard Art Museums, 2013.

—. "The Itinerant Dragon-Slayer: Forging Paths of Image and Identity in Medieval Anatolia." Gesta 43.2 (2004): 151-64.

Park, David. “The 'Lewes Group' of Wall Painting in Sussex.” Anglo-Norman Studies 6 (1983): 200-37.

Peacock, A. C. S. The Great Seljuk Empire. Edinburgh: Edinburgh University Press, 2015.

Piatnitsky, Yuri A. "K istorii postuleniia v Ermitazh bizantiı̆ckol̆ sererianol̆ chashi XII veka." In Vizantiia v kontekste mirovor istorii: Materialy nauchnol̆ konferentsii, posviashchennŏ pamiati A. V. Bank, edited by V. N. Zalesskaia, 128-39. Saint Petersburg: Izd-vo Gosudarstvennyı̆ Ermitazha, 2004. 
— - et al. Sinai, Byzantium, Russia: Orthodox Art from the Sixth to the Twentieth Century. London: Saint Catherine Foundation, 2000.

Raffensperger, Christian. Reimagining Europe: Kievan Rus' in the Medieval World. Cambridge, MA: Harvard University Press, 2012.

Restle, Marcell. Die byzantinische Wandmalerei in Kleinasien, 2 vols. Recklinghausen: A. Bongers, 1967.

Shepherd, Dorothy. "Banquet and Hunt in Medieval Islamic Iconography." In Gatherings in Honor of Dorothy E. Miner, edited by Ursula E. McCracken et al., 79-92. Baltimore: Walters Art Gallery, 1974.

Shoshan, Boaz. "High Culture and Popular Culture in Medieval Islam." Studia Islamica 73 (1991): 67-107.

Shukurov, Rustam. "Harem Christianity: The Byzantine Identity of Seljuq Princes." In The Seljuks of Anatolia: Court and Society in the Medieval Middle East, edited by A. C. S. Peacock and Sara Nur Yıldız, 115-50. London: I. B. Tauris, 2012.

—. "Turkmen and Byzantine Self-Identity: Some Reflections on the Logic of the Title-Making in Twelfth- and Thirteenth-Century Anatolia." In Eastern Approaches to Byzantium, edited by Antony Eastmond, 255-72. Aldershot: Ashgate, 2001.

Stone, Andrew. "Eustathios and the Wedding Banquet for Alexios Porphyrogennetos." In Feast, Fast or Famine: Food and Drink in Byzantium, edited by Wendy Mayer and Silke Trzcionka, 33-42. Brisbane: Australian Association for Byzantine Studies, 2005.

Tronzo, William. The Cultures of His Kingdom: Roger II and the Cappella Palatina in Palermo. Princeton: Princeton University Press, 1997.

Walker, Alicia. The Emperor and the World: Exotic Elements and the Imaging of Middle Byzantine Imperial Power, Ninth to Thirteenth Centuries C.E. New York: Cambridge University Press, 2012.

—. "Globalism." In Medieval Art History Today: Critical Terms, edited by Nina Rowe, special issue of Studies in Iconography 33 (2012): 183-96.

—. "Integrated yet Segregated: Eastern Islamic Art in Twelfth-Century Byzantium." In Festschrift for Henry Maguire, edited by Rossitza Schroeder and Andrea Lam, forthcoming 2018.

— - and Amanda Luyster, eds. Negotiating Secular and Sacred in Medieval Art and Architecture: Christian, Islamic, Buddhist. Burlington, VT: Ashgate, 2009.

Walter, Christopher. "The Origins of the Cult of St. George." Revue des études byzantines 53.1 (1995): 295-326.

—. The Warrior Saints in Byzantine Art and Tradition. Aldershot, UK: Ashgate, 2003.

Wirth, P., ed. Eustathii Thessalonicensis opera minora. Berlin: De Gruyter, 2000.

Wolper, Ethel Sara. "Khiḍr and the Changing Frontiers of the Medieval World." Medieval Encounters 17 (2011): 120-46. 
—_. "Khiḍr, Elwan Çelebi and the Conversion of Sacred Sanctuaries in Anatolia." The Muslim World 90 (2000): 309-22.

—. "Khiḍr and the Politics of Place: Creating Landscapes of Continuity." In Muslims and Others in Sacred Space, edited by Margaret Cormack, 147-63. Oxford: Oxford University Press, 2013.

Woodfin, Warren. "Within a Budding Grove: Dancers, Gardens, and the Enamel Cup from the Chungul Kurgan." Art Bulletin 98.2 (2016): 151-80.

Alicia Walker (awalker01@brynmawr.edu) is Associate Professor of Medieval Art and Architecture at Bryn Mawr College. Her primary fields of research include cross-cultural artistic interaction in the medieval world from the ninth to thirteenth centuries and gender issues in the art and material culture of Byzantium. Her first book, The Emperor and the World: Exotic Elements and the Imaging of Byzantine Imperial Power, was published by Cambridge University Press in 2012. She is currently at work on her second monograph, provisionally titled The Erotic Eye in Byzantium, which explores the role of Greco-Roman iconography in the expression and regulation of female sexuality in early and middle Byzantine art and material culture.

Abstract In the twelfth century, Christian military saints, including George and Theodore, became intercultural heroic figures. Appearing in works of art across western European, Byzantine, Crusader, and Islamic cultural spheres, these holy heroes sometimes featured in contexts and objects that modern taxonomies classify as "secular." This article focuses on a particularly intriguing example of this phenomenon: a middle Byzantine silver drinking cup, which displays on its exterior a program of so-called princely cycle imagery derived from medieval Islamic courtly iconography, but contrasts these decidedly non-religious motifs with a portrait of Saint George on the interior bottom of the vessel. By excavating the logic of the cup's iconography-its inclusion of George at a banquet-it aims to overcome the insufficiencies of conventional, modern terminology and taxonomies for medieval art by engaging with the transcultural complexity of elite leisure culture in the medieval world.

Keywords Byzantine, Seljuq, dining ware, silver, secular, transcultural, Saint George, Crusades 


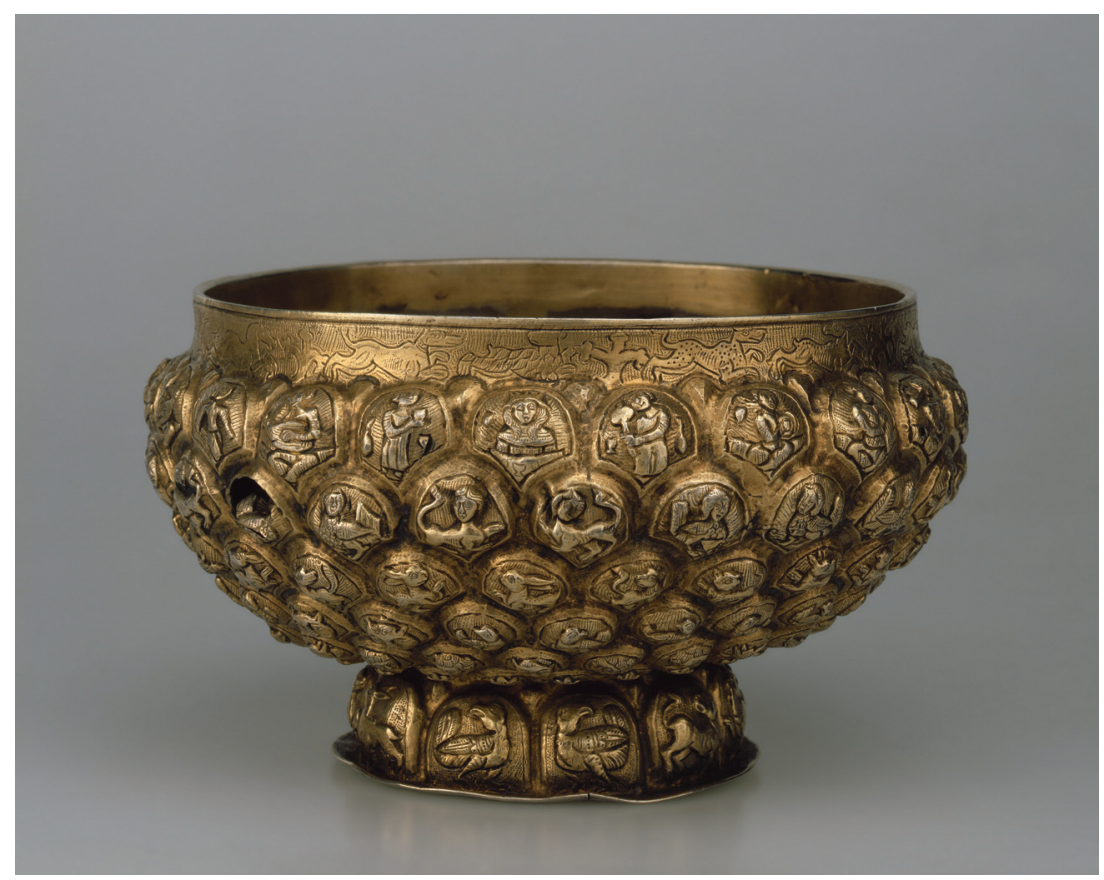

Plate 6.1. Beryozovo Cup: Byzantine, twelfth century. Gilded silver, height: $11.6 \mathrm{~cm}$; diameter: $18.5 \mathrm{~cm}$. St. Petersburg, The State Hermitage Museum, inv. no W-3. (c) The State Hermitage Museum / photo by Vladimir Terebenin.

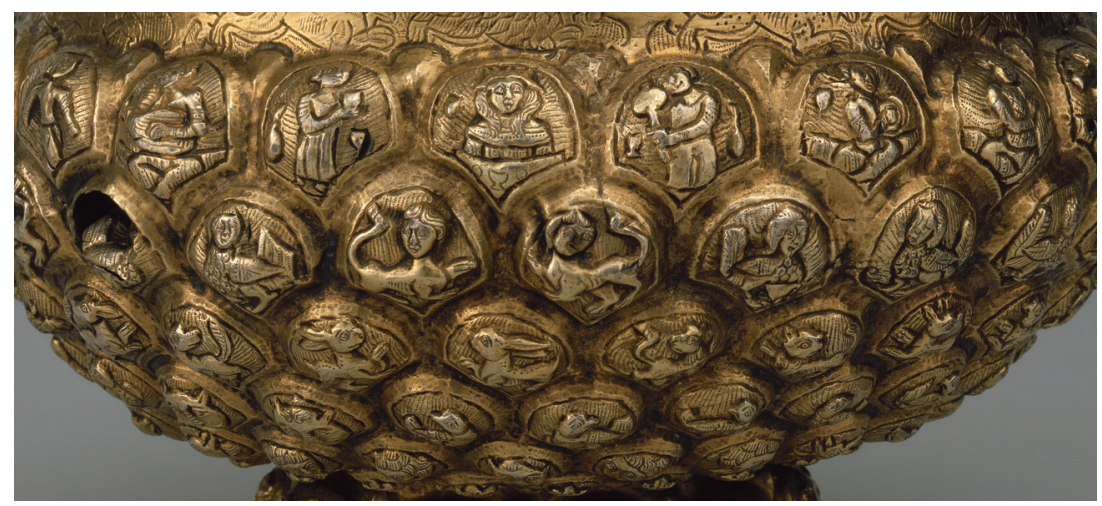

Plate 6.2. Detail of Plate 6.1, showing lobes decorated with human and animal figures. (C) The State Hermitage Museum / photo by Vladimir Terebenin. 


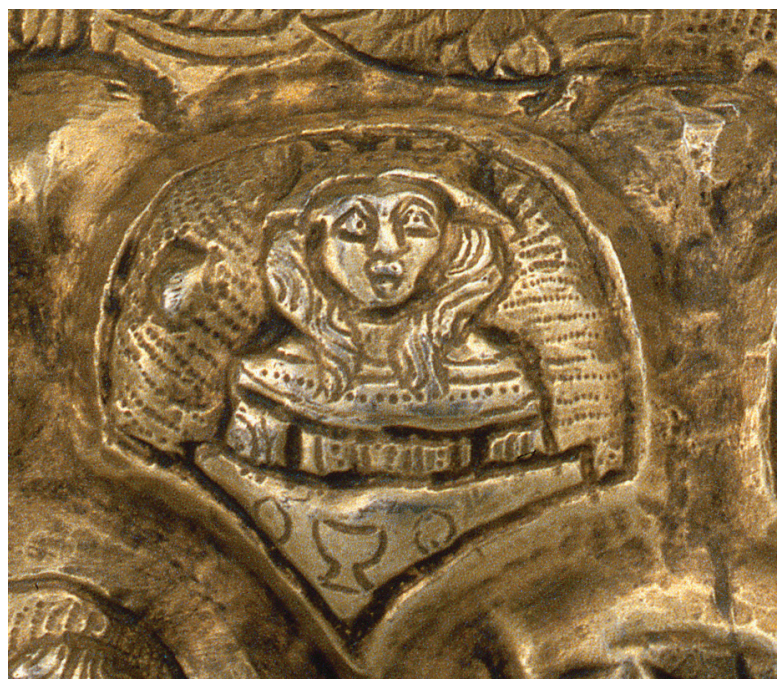

Plate 6.3. Detail of Plate 6.1, showing female figure at a banquet. (c) The State Hermitage Museum / photo by Vladimir Terebenin.

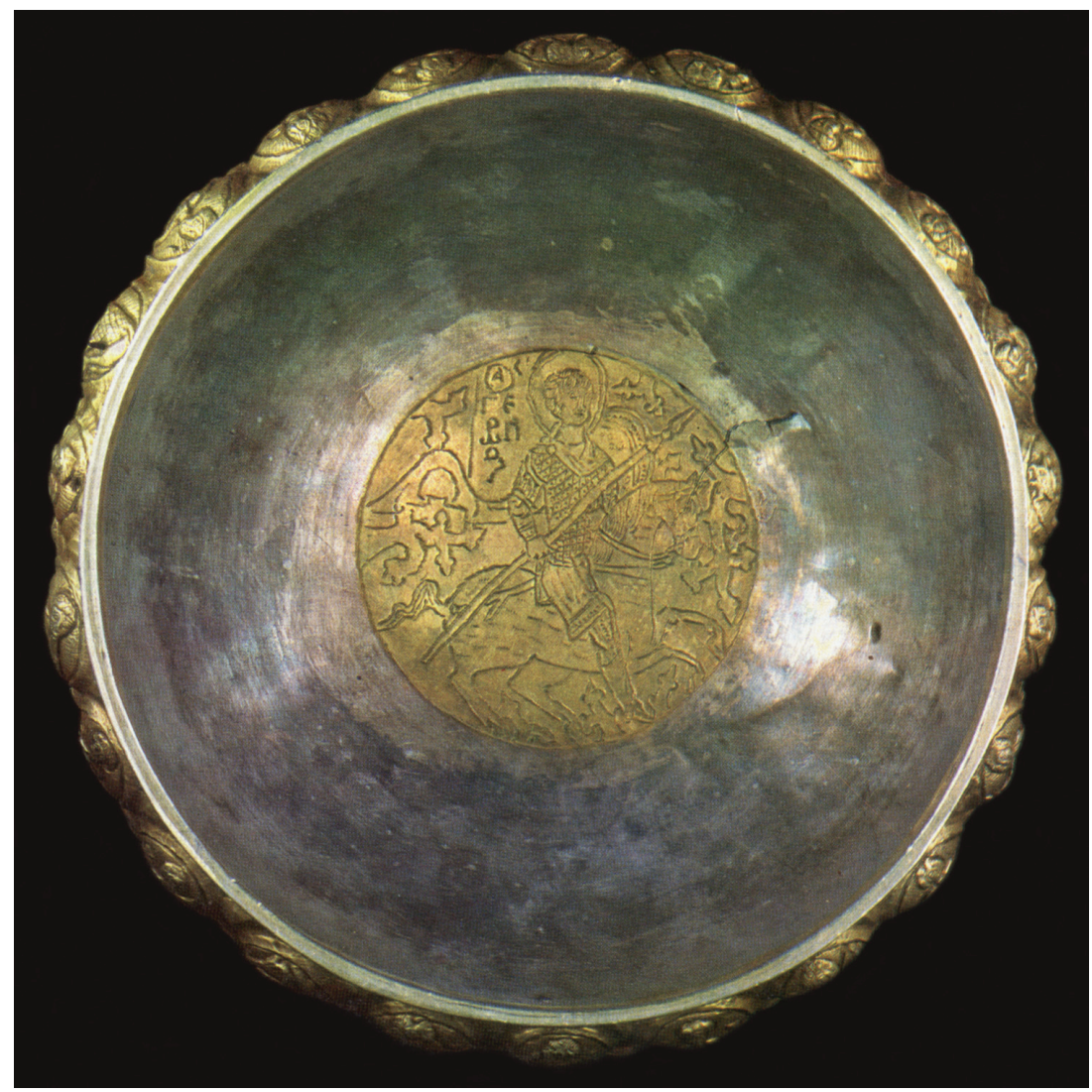

Plate 6.4. Detail of the Beryozovo Cup (see Plate 6.1), showing interior of the vessel displaying an image of Saint George.

(c) The State Hermitage Museum / photo by Vladimir Terebenin. 


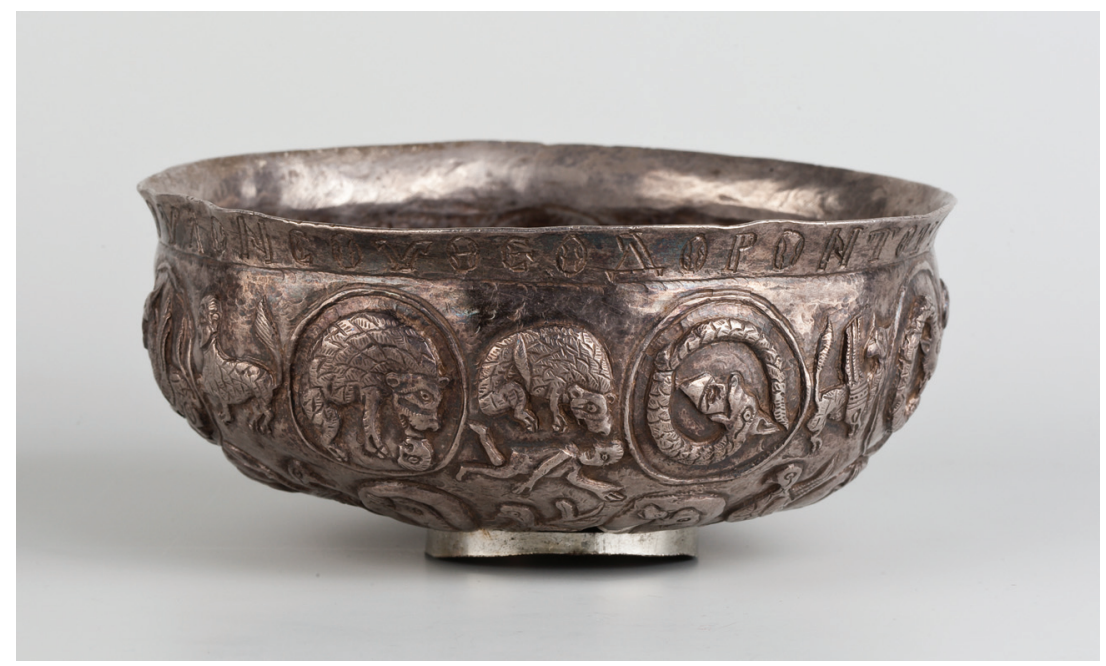

Plate 6.5. Cup: Byzantine, eleventh century. Silver, height: $5 \mathrm{~cm}$; diameter: $14 \mathrm{~cm}$. St. Petersburg, The State Hermitage Museum, inv. no. W-1193.

(C) The State Hermitage Museum / photo by Svetlana Suetova, Konstantin Sinyavskiy.

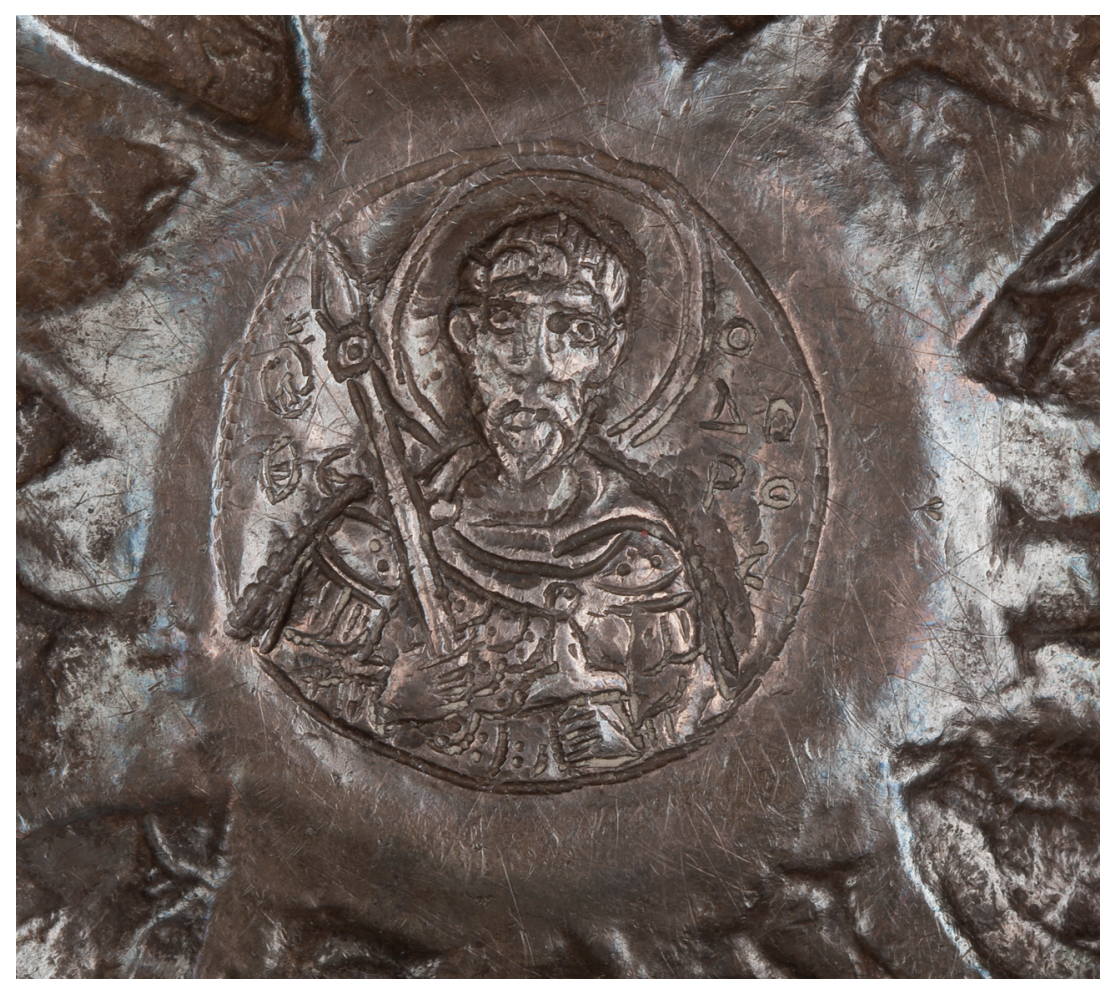

Plate 6.6. Detail of cup (see Plate 6.5), showing interior of the vessel displaying an image of Saint Theodore.

(C) The State Hermitage Museum / photo by Svetlana Suetova, Konstantin Sinyavskiy. 


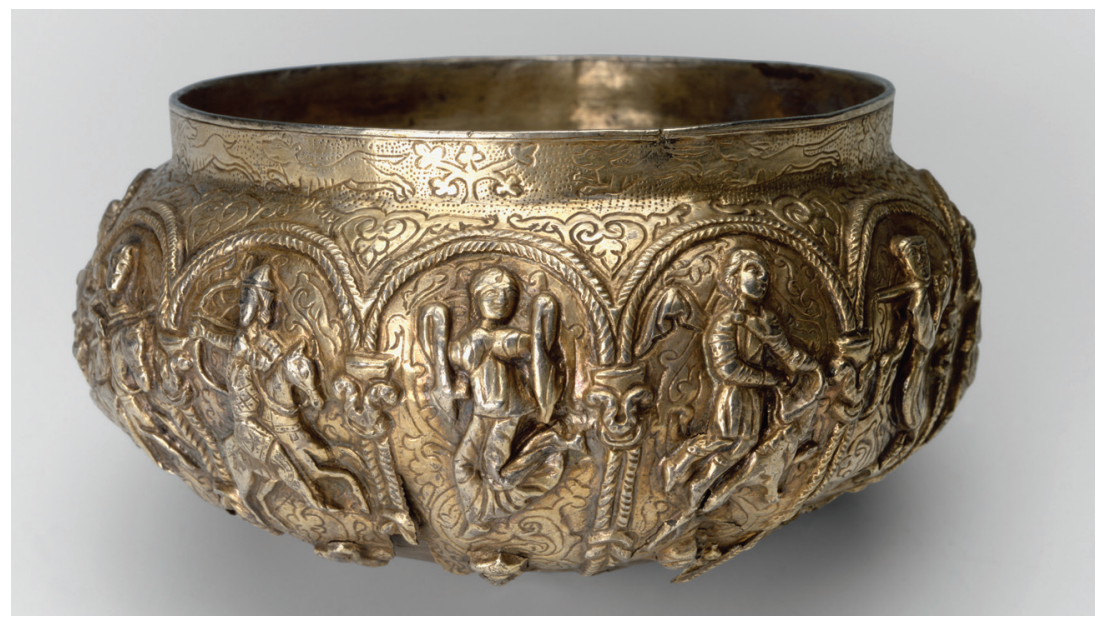

Plate 6.7. Cup with heroic figures under arches: Byzantine, twelfth century. Gilded silver, height: $9.5 \mathrm{~cm}$; diameter: $17 \mathrm{~cm}$. St. Petersburg, The State Hermitage Museum, inv. no W-72. (C) The State Hermitage Museum / photo by Vladimir Terebenin.
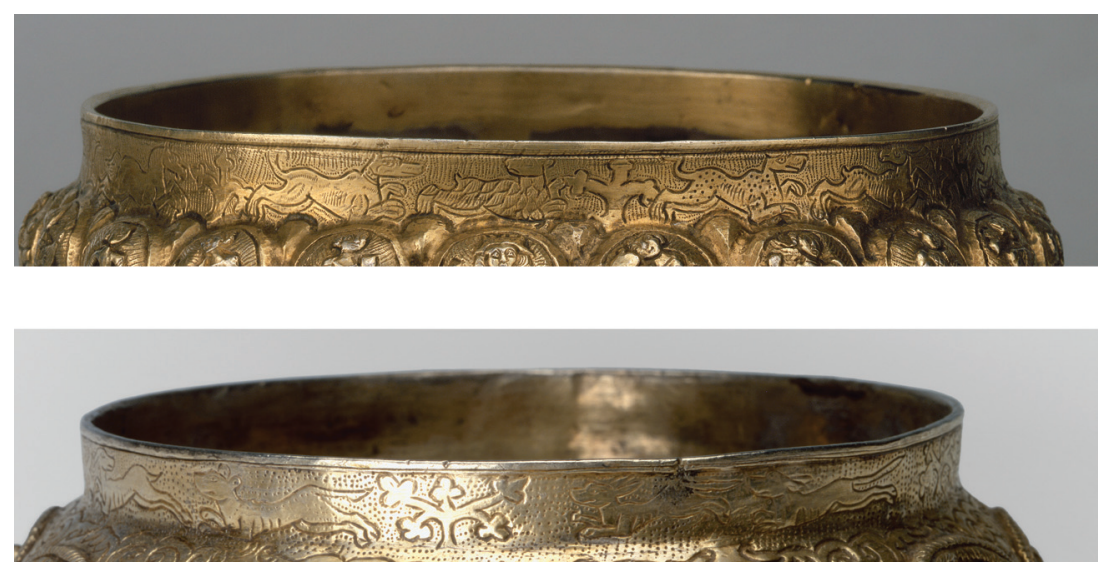

Plate 6.8. Comparison of decorative borders in the rims of Plates 6.1 (top) and 6.7 (bottom). (c) The State Hermitage Museum / photos by Vladimir Terebenin. 


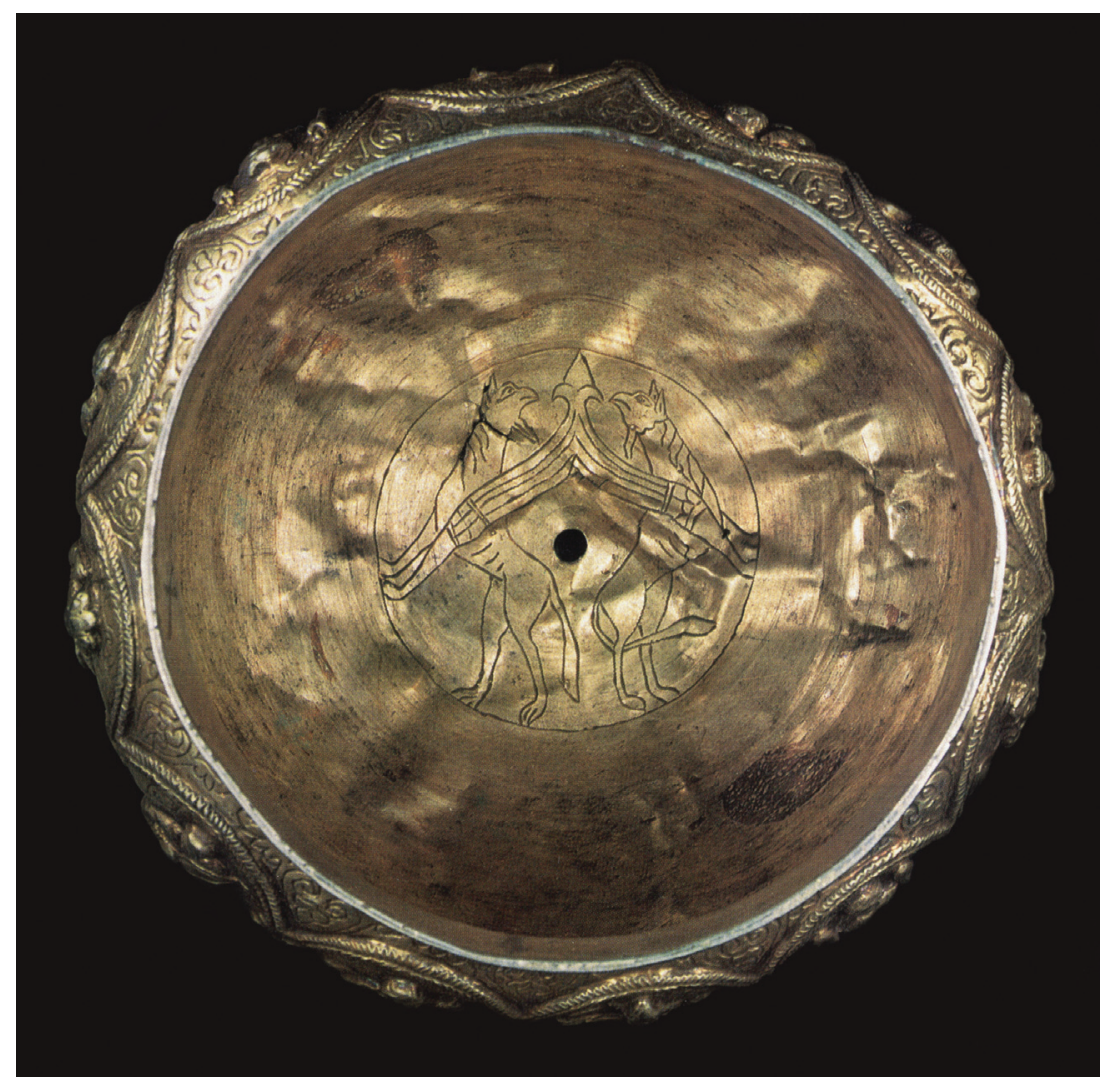

Plate 6.9. Detail of cup (see Plate 6.8), showing interior of the vessel. (C) The State Hermitage Museum / photo by Vladimir Terebenin. 


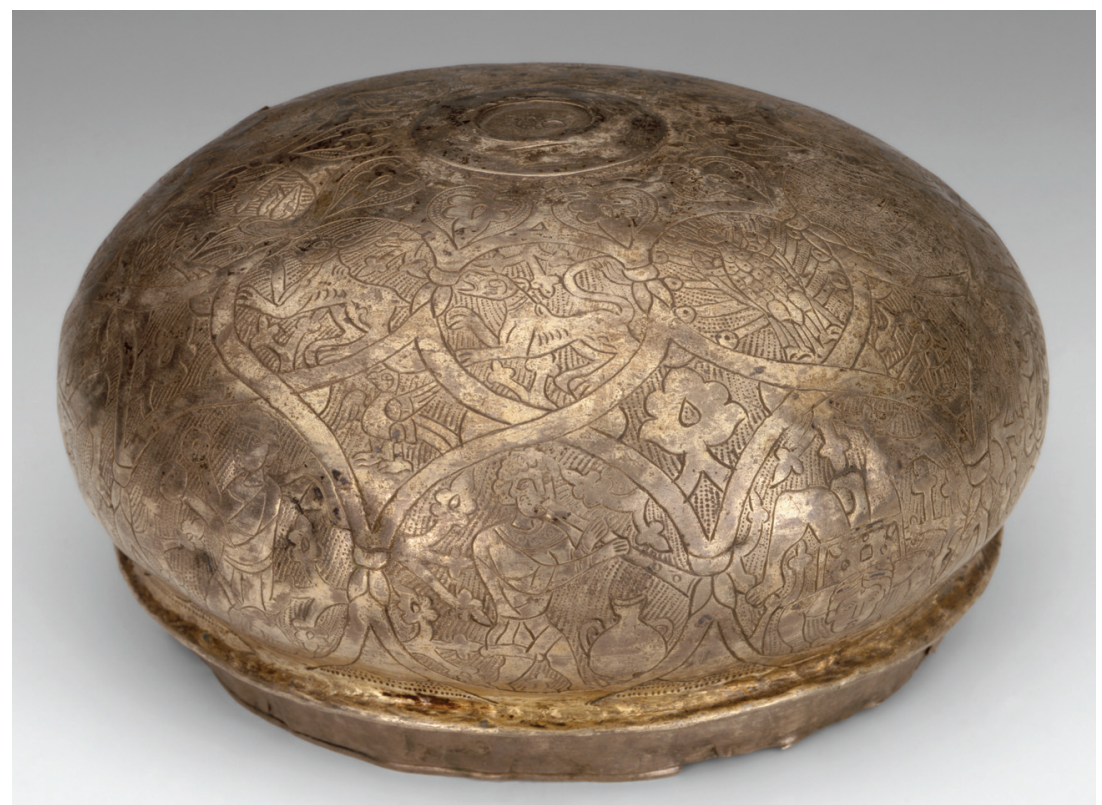

Plate 6.10. Lid from a cup: Byzantine, twelfth century. Silver, height: $9 \mathrm{~cm}$; diameter: 16 cm. St. Petersburg, The State Hermitage Museum, inv. no. W-1193.

(C) The State Hermitage Museum / photo by Vladimir Terebenin.
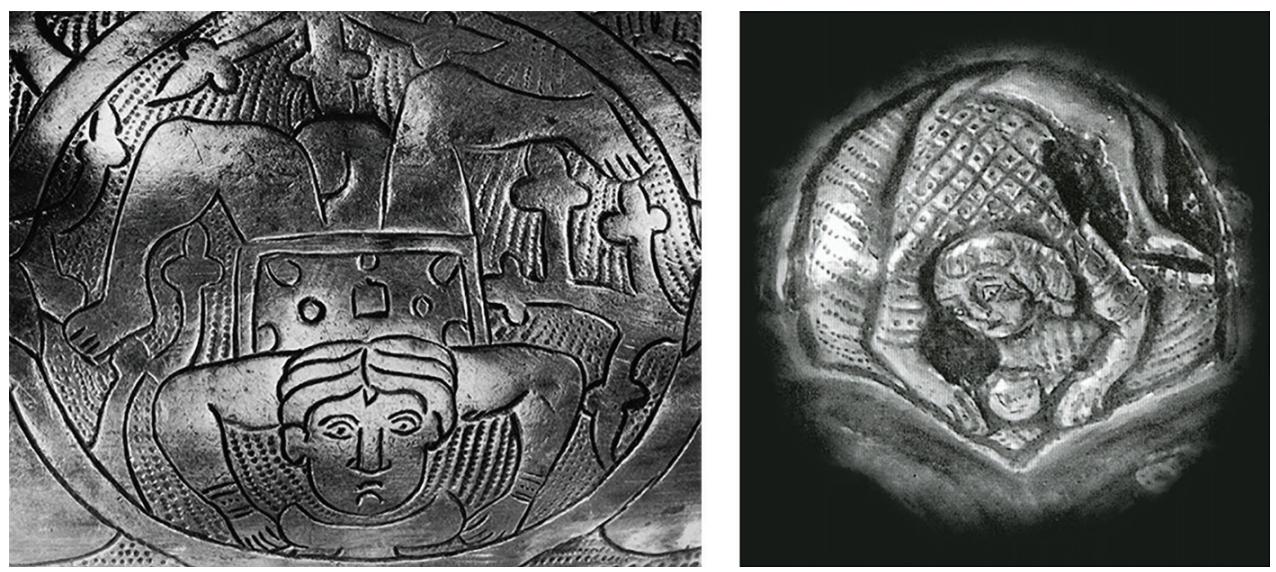

Plate 6.11. Comparison of motifs showing an acrobat standing on his hands and drinking from his cup: details of Plates 6.10 (left) and 6.1 (right). (C) The State Hermitage Museum / photos by Vladimir Terebenin. 


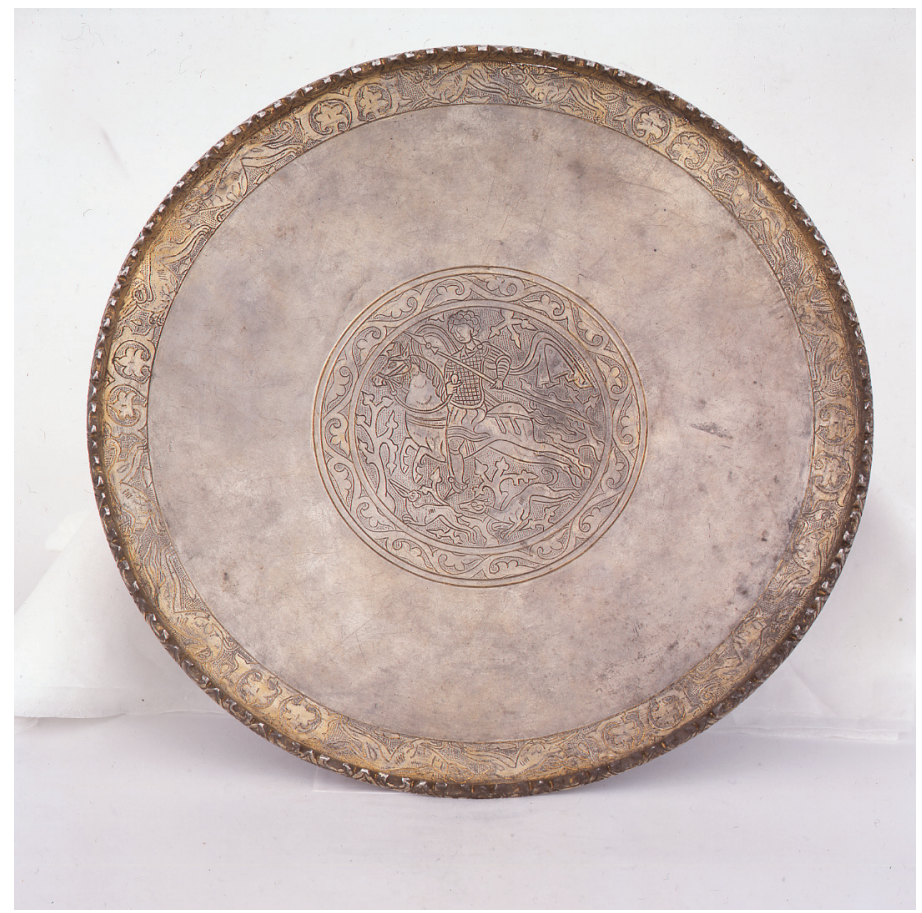

Plate 6.12. Plate: Byzantine, twelfth century. Silver, height: $5.5 \mathrm{~cm}$; diameter: $29 \mathrm{~cm}$. Photo courtesy of the Benaki Museum, Athens.
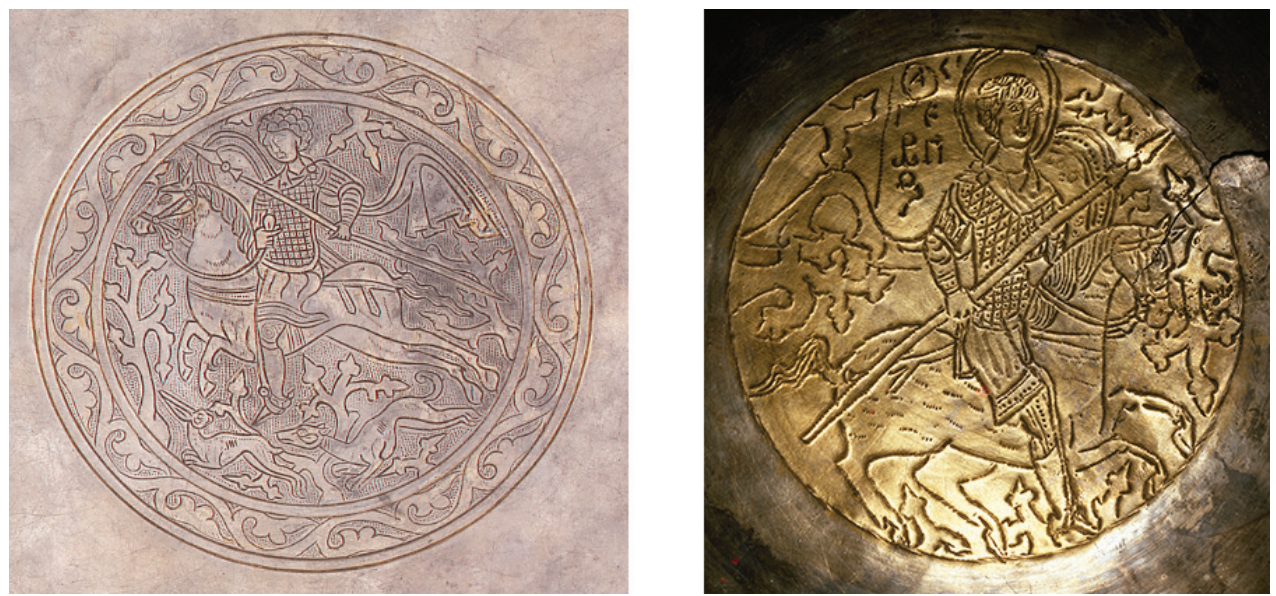

Plate 6.13. Comparison of motifs showing rider figures: details of Plates 6.12 (left) and 6.4 (right). 


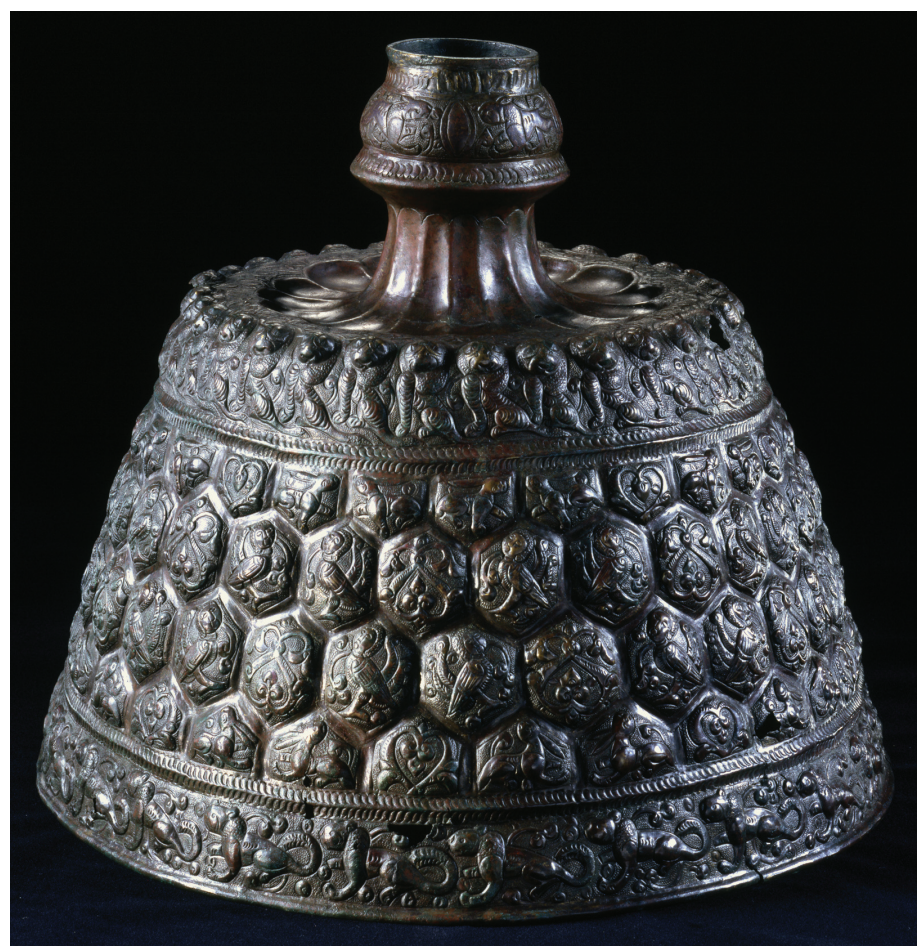

Plate 6.14. Candlestick: Ghurid or Ghaznavid, from eastern Iran or Afghanistan, ca. 11501200. Brass, height: $33 \mathrm{~cm}$; diameter: $40 \mathrm{~cm}$. Copenhagen, The David Collection, inv. no. 27 / 1971. Photograph: Pernille Klemp.

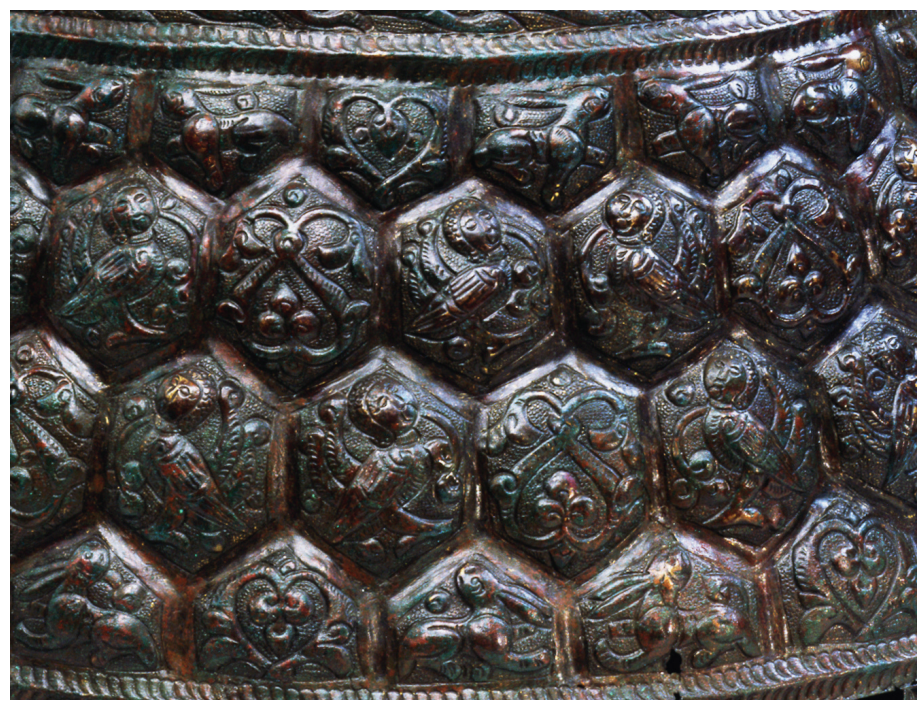

Plate 6.15. Detail of Plate 6.14: lobes depicting plants and animals. Photograph: Pernille Klemp. 


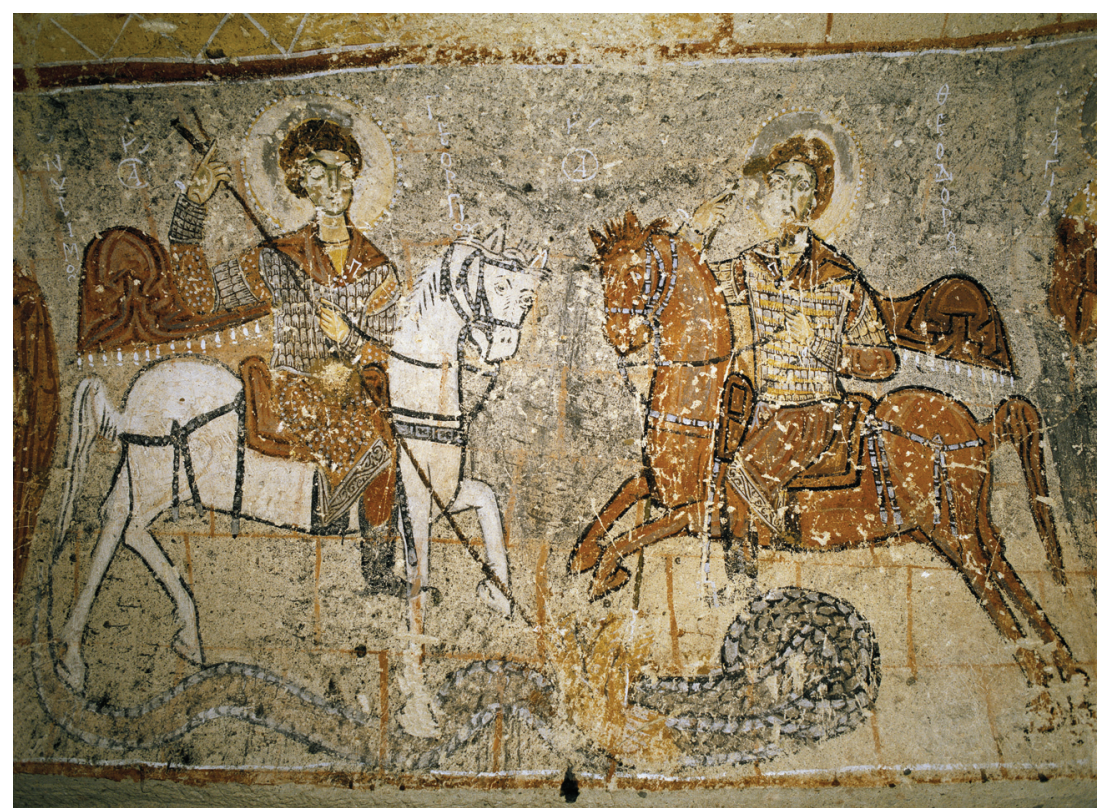

Plate 6.16. Saint George and Saint Theodore attacking a snake: Byzantine, eleventh century. Wall painting from Yllanlı Kilise (Snake Church), Göreme, Cappadocia (Turkey). Photo: David Ball / Alamy Stock Photo.
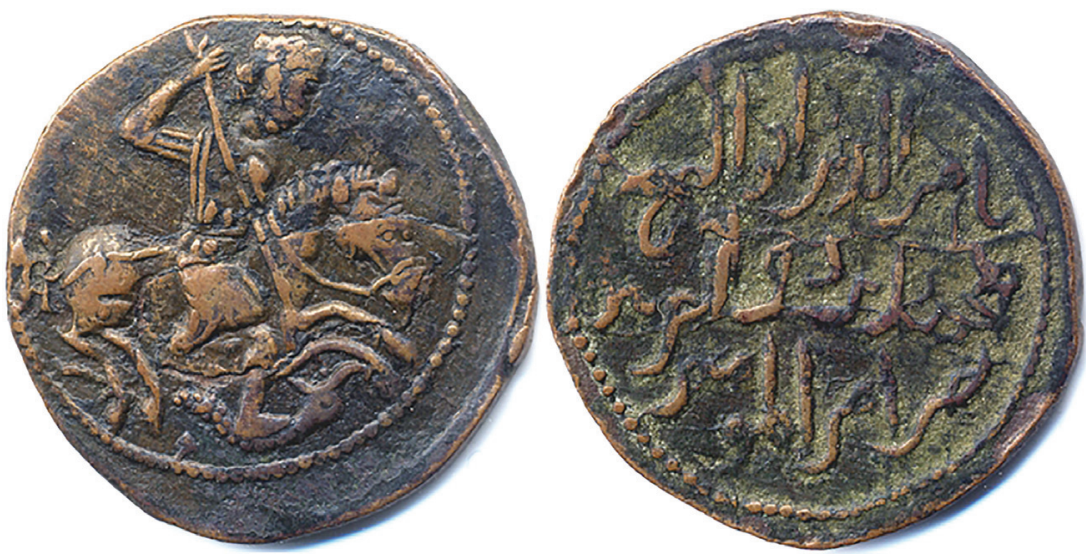

Plate 6.17. Dirham of Nasir al-Din Muhammad from Danishmendid, Malatya (Turkey), 1162-78. Copper alloy, diameter: $3 \mathrm{~cm}$. American Numismatic Society, 1916.215.840. Courtesy of the American Numismatic Society. 


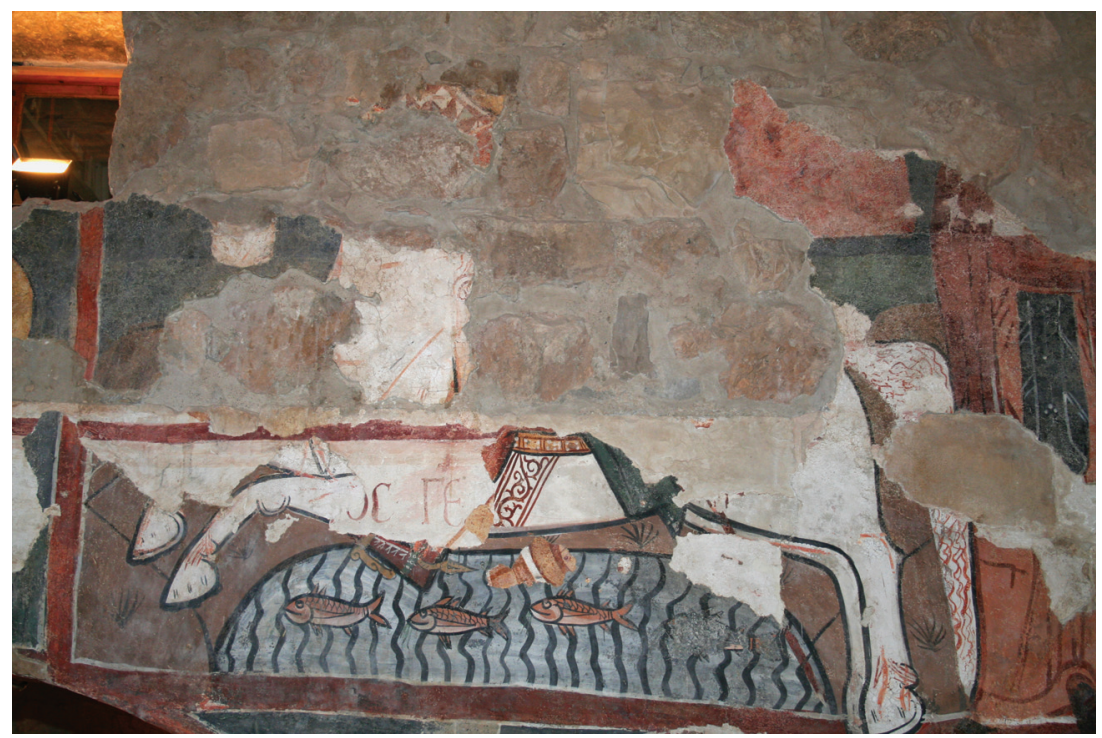

Plate 6.18. Saint George on horseback, ca. 1060. Wall painting from Deir Mar Musa al-Habashi, near Nebk, Syria. Photo courtesy of the Paul van Moorsel Centre, Vrije Universiteit Amsterdam / Mat Immerzeel.

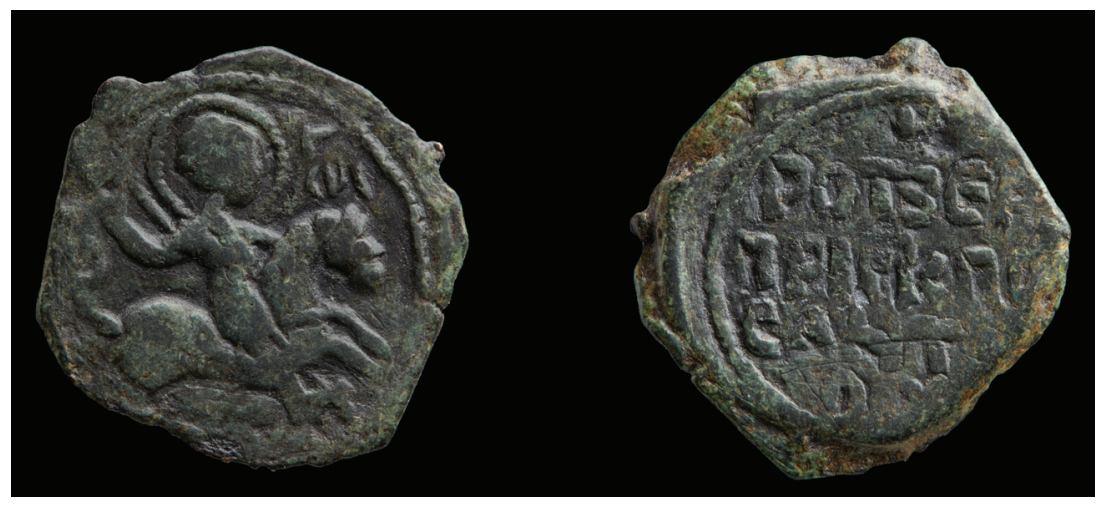

Plate 6.19. Copper coin featuring Saint George on the obverse: Antiochene Mint of Roger of Salerno, Crusader, 1112-19. Oxford, Ashmolean Museum, acc. no. HCR43814. Image (C) Ashmolean Museum, University of Oxford. 